\title{
Tumor-initiating cells of breast and prostate origin show alterations in the expression of genes related to iron metabolism
}

\author{
Zuzana Rychtarcikova ${ }^{1,2, *}$, Sandra Lettlova ${ }^{1,3, *}$, Veronika Tomkova ${ }^{1,3}$, Vlasta \\ Korenkova $^{1}$, Lucie Langerova ${ }^{1}$, Ekaterina Simonova ${ }^{1}$, Polina Zjablovskaja ${ }^{4}$, \\ Meritxell Alberich-Jorda ${ }^{4}$, Jiri Neuzil ${ }^{1,5}$, Jaroslav Truksa ${ }^{1}$ \\ ${ }^{1}$ Institute of Biotechnology, Czech Academy of Sciences, Prague, Czech Republic \\ ${ }^{2}$ Charles University in Prague, Faculty of Pharmacy in Hradec Kralove, Hradec Kralove, Czech Republic \\ ${ }^{3}$ Charles University in Prague, Faculty of Sciences, Prague, Czech Republic \\ ${ }^{4}$ Institute of Molecular Genetics, Czech Academy of Sciences, Prague, Czech Republic \\ ${ }^{5}$ School of Medical Science, Menzies Health Institute Queensland, Southport, Queensland, Australia \\ *These authors contributed equally to this work
}

Correspondence to: Jaroslav Truksa, email: jaroslav.truksa@ibt.cas.cz

Keywords: tumor-initiating cells, breast cancer, iron metabolism, FeS cluster, stem cells

Received: January 12, $2016 \quad$ Accepted: November 30, $2016 \quad$ Published: December 22, 2016

\section{ABSTRACT}

The importance of iron in the growth and progression of tumors has been widely documented. In this report, we show that tumor-initiating cells (TICs), represented by spheres derived from the MCF7 cell line, exhibit higher intracellular labile iron pool, mitochondrial iron accumulation and are more susceptible to iron chelation. TICs also show activation of the IRP/IRE system, leading to higher iron uptake and decrease in iron storage, suggesting that level of properly assembled cytosolic ironsulfur clusters (FeS) is reduced. This finding is confirmed by lower enzymatic activity of aconitase and FeS cluster biogenesis enzymes, as well as lower levels of reduced glutathione, implying reduced FeS clusters synthesis/utilization in TICs. Importantly, we have identified specific gene signature related to iron metabolism consisting of genes regulating iron uptake, mitochondrial FeS cluster biogenesis and hypoxic response (ABCB10, ACO1, CYBRD1, EPAS1, GLRX5, HEPH, HFE, IREB2, QSOX1 and $T F R C$ ). Principal component analysis based on this signature is able to distinguish TICs from cancer cells in vitro and also Leukemia-initiating cells (LICs) from non-LICs in the mouse model of acute promyelocytic leukemia (APL). Majority of the described changes were also recapitulated in an alternative model represented by MCF7 cells resistant to tamoxifen (TAMR) that exhibit features of TICs. Our findings point to the critical importance of redox balance and iron metabolism-related genes and proteins in the context of cancer and TICs that could be potentially used for cancer diagnostics or therapy.

\section{INTRODUCTION}

Iron is an indispensable micro-nutrient, on which most living organisms depend for their existence due to its ability to shuffle between ferrous and ferric form and participate in crucial redox reactions. Iron also serves as a metal cofactor needed for DNA synthesis and repair as well as a cofactor of many metabolic enzymes and enzymes of the respiratory complexes in mitochondria $[1,2,3]$.
There are many iron metabolism-related proteins that play pivotal role in cellular iron handling, for example proteins related to iron uptake such as transferrin receptor (TFR1 encoded by the TFRC) and cytochrome $\mathrm{b}$ reductase (coded by CYBRDI) $[3,4]$ as well as regulators participating in iron storage such as ferritin encoded by the FTH and FTL genes [5]. Additional proteins participating in the iron utilization and $\mathrm{FeS}$ cluster assembly are glutaredoxin 5 (encoded by GLRX5) and ATP binding cassette subfamily B member 10 (coded 
by $A B C B 10)[1,6,7]$. There are other critical enzymes participating in the iron sensing such as iron responsive protein 1 (IRP1) encoded by the aconitase (ACO1) gene and iron responsive protein 2 (IRP2) coded by the iron responsive element binding protein 2 (IREB2) gene [8]. These proteins play a crucial role in assessing the intracellular iron level and eliciting appropriate response by modulating iron uptake and iron storage via binding to the iron responsive elements (IRE) located at the 5 ' and 3 'prime untranslated regions of the corresponding mRNA [9]. Furthermore, there is a tight crosstalk between the hypoxic response of the cell and cellular iron metabolism as low iron levels elicit activation of the hypoxia inducible factors (HIF) encoded by the HIFIA and endothelial Per-ARNT-Sim Domain Protein 1 (EPAS1) genes [10]. Activation of these genes is connected with higher iron uptake through CYBRD1 in the enterocytes [11] and in the non-physiological setting it is connected with activation of tissue remodelling factors such as quiescin sulfhydryl oxidase1 (coded by QSOX1) [12]. Other important regulators of iron metabolism represent proteins involved in iron export such as hephaestin encoded by the $H E P H$ gene and ferroportin ecoded by the solute carrier family 40 member 1 (SLC40A1) gene [13, 14]. Additional proteins participating in the iron uptake and non-transferrin bound iron uptake (NTBI) such as natural resistance associated protein (NRAMP2) coded by the solute carrier family 11 member 2 (SLC11A2) gene and zinc importer protein 14 (ZIP14) encoded by the solute carrier family 39 member 14 (SLC39A14) play an important role in the cellular and systemic iron metabolism together with the hemochromatosis (HFE) gene and protein which is connected with excessive iron loading [3,15-20]

The role of iron in the progression and growth of tumor cells has been documented in various studies describing higher iron uptake in cancer cells due to their proliferative nature and altered metabolic needs [21-23]. The correlation between the iron content in the diet and tumorigenesis has also been proposed, suggesting iron as a risk factor for some cancer subtypes, such as haematological malignities or hepatocellular carcinoma. Molecular mechanisms underlying this phenomenon are diverse and include higher iron uptake via transferrin receptor, activation of hypoxia-inducible factors (HIFs) in cancer cells due to compromised function of the prolyl hydroxylases and deregulation of signaling pathways such as $\mathrm{Wnt} / \beta$-catenin [24-31].

It has been shown that iron-deprivation is able to induce apoptosis in tumor cells, particularly in cells of hematopoietic origin. Additionally, gallium nitrate, a competitor of the iron ion, has been successfully used to treat bladder cancer in a clinical setting [32-35].

The concept of cancer stem cells (CSC) or tumorinitiating cells (TICs) has emerged recently, documenting the extreme plasticity and heterogeneity of tumor tissue. This concept states that only a small sub-fraction of tumor cells is able to initiate tumor growth in vivo and that cells possessing this capability cause residual disease leading to relapse and death, although it is probably not universal concept for all cancer types [36-38]. This is of crucial clinical importance and there is virtually no data on iron metabolism in these cells, with only emerging evidence that HIFs play an important role in their maintenance and renewal [39-48].

Recently, there have been several attempts to correlate iron metabolism-related genes with the survival and overall prognosis of tumor progression in breast cancer patients. Miller et al. have shown that loss of the iron excretory genes and also upregulation of the iron uptake machinery impacts the prognosis and can delineate patients that would respond well in the group of hard-totreat individuals and vice versa [49]. However, changes in the expression of these genes in TICs remains elusive so far.

Our study provides an insight into iron metabolism of TICs, their response to iron withdrawal, and identifies a specific gene signature related to iron metabolism that is differentially expressed in TICs. We have also identified iron metabolism-related proteins that are differentially expressed in TICs and could be utilized in cancer diagnosis or treatment.

\section{RESULTS AND DISCUSSION}

There are virtually no data concerning the role of iron and its metabolism in the maintenance and selfrenewal of tumor-initiating cells (TICs) as yet. We thus focused our study on this particular topic and assessed iron content, sensitivity to iron chelators, iron uptake and storage, intracellular iron distribution and expression profile of iron metabolism-related genes in TICs.

\section{Spheres as an in vitro model of TICs}

We have used previously published methods to generate cells growing as spheres from the breast cancer cell line MCF7 via two alternative methods. The first method is based on serum-free medium and cells generated by this method are referred to as "spheres" [50]. An alternative method [51] based on the nonadherent plastic resulted in cells referred to as "agar". In our experience, the serum-free approach generated spheres with more profound expression of stem cell/ epithelia-mesenchymal transition (EMT) markers, yet in some cell lines such as DU-145, only the agar approach worked as they did not form spheres under serum-free conditions. We also included a non-malignant cell line of breast origin, MCF-10A; we were unable to generate spheres from these cells by either of the above mentioned approaches, pointing to the fact that malignant but not immortalized cells are able to form spheres in our hands. The appearance of MCF7 spheres is depicted in 
Figure 1A and Supplementary Figure S1 shows expression of identical markers in all tested cell lines, documenting successful generation of spheres that represent in vitro model of TICs.

\section{MCF7 spheres show higher labile iron pool (LIP) and iron uptake, higher amount of iron within mitochondria and are sensitive to iron chelation}

In order to characterize iron metabolism of TICs, we first inspected the level of LIP within the MCF7 sphere cells using the calcein fluorescence-based approach [52] and found significantly higher level of LIP in TICs (Figure 1B). To confirm our findings, we examined the ability of cells to acquire radioactive ${ }^{55} \mathrm{Fe}$ and demonstrated that MCF7 spheres show significantly higher cellular ${ }^{55} \mathrm{Fe}$ uptake (Figure 1C) and significantly higher ${ }^{55} \mathrm{Fe}$ level in mitochondria (Figure 1D).

Further tests showed that application of cell permeable iron chelator such as salicyl isonicotinoyl hydrazone (SIH) resulted in decreased survival of MCF7 spheres compared to control adherent cells as measured by the Cell Titer-Glo (Figure 1E) and Cell Titer-Fluor (Figure 1F) cell viability assays. MCF7 spheres lost their ATP levels much faster and also exhibited higher numbers of dead cells compared to controls (Figure 1E-1F).

These data document higher iron uptake and labile iron pool, differential intracellular iron distribution with mitochondrial iron accumulation in MCF7 spheres as well as the necessity of iron for their survival. In order to find the underlying mechanism explaining this phenomenon, we performed expression profiling of genes that are related to iron metabolism.

\section{TICs derived from various cancer cell lines show deregulation of genes related to iron metabolism}

We performed expression profiling of selected 40 genes that cover iron uptake, export, transport, utilization, FeS cluster biogenesis, heme metabolisms, hypoxia inducible factors and other important regulators of iron metabolism in TICs generated from MCF7, BT474, T-47D, ZR-75-30 breast and LNCaP and DU145 prostate cancer cells. We obtained expression profiles of 34 selected iron metabolism-related genes that were detectable and showed acceptable qPCR standard curves. Raw data showing actual values and genes tested are supplied in Supplementary Table S3.

We then compared the fold change in mRNA expression between TICs prepared by the sphere approach and control cells (Supplementary Table S1) and selected genes with altered expression $(>1.5$ fold change in mRNA expression) that is reproducible among cell lines (a similar change occurs in more than $60 \%$ of cell lines), resulting in the iron metabolism-related gene signature differentially expressed in TICs $(A B C B 10$, ACO1, CYBRD1, EPAS1, GLRX5, HEPH, HFE, IREB2, $Q S O X 1$ and $T F R C$ ). Individual genes participating in the
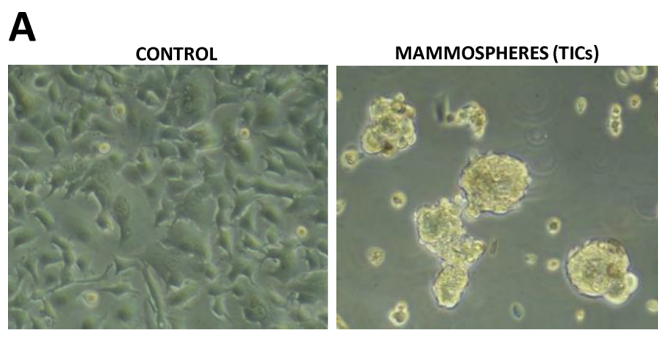

D

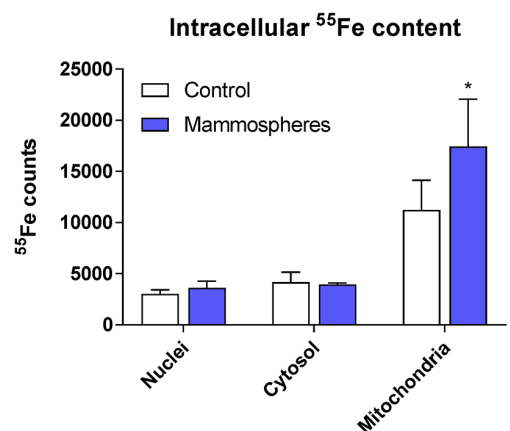

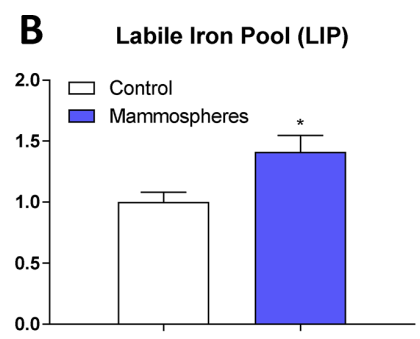

$\mathbf{E}$

Cell Titer-Glo' ${ }^{\text {TM }}$ Cell Viability Assay

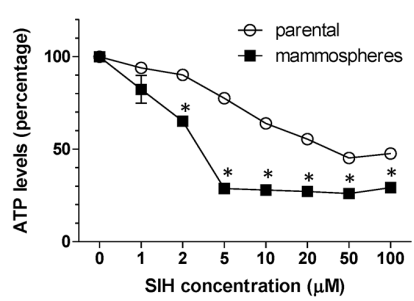

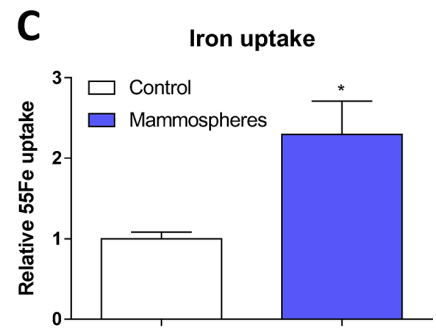

$\mathbf{F}$

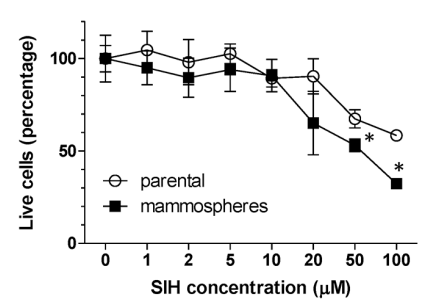

Figure 1: Appearance, labile iron pool, iron uptake, intracellular localization and sensitivity to chelators in tumorinitiating cells (TICs). The appearance of MCF7 cell grown either under control or sphere forming conditions is shown (A), together with Labile iron pool (LIP) detected by the calcein method (B), assessment of the ${ }^{55} \mathrm{Fe}$ uptake $(\mathbf{C})$ and intracellular distribution of ${ }^{55} \mathrm{Fe}(\mathbf{D})$. Cells were also assayed for their resistance to cell death by two approaches - Cell Titer-Glow (E) and Cell Titer-Fluor (F). Experiments were performed at least in triplicate, standard error is SEM. $P$-values lower than 0.05 are denoted with a star and were calculated by the GraphPad Prism software using the unpaired $t$-test. 
iron uptake (CYBRD1, TFRC), iron sensing and regulation (ACO1, IREB2), mitochondrial iron-sulphur cluster assembly ( $A B C B 10, G L R X 5)$, hypoxia response (EPAS1, $Q S O X 1)$, iron export $(H E P H)$ and iron overload (HFE) are discussed below.

\section{Expression of cytochrome b reductase (CYBRD1) and transferrin receptor 1 (TFR1) participating in iron uptake is higher in TICs}

CYBRD1 is an enzyme highly expressed at the duodenal brush border membrane. Product of the $C Y B R D 1$ gene reduces ferric iron to ferrous iron and plays an important role in iron uptake from the intestine [4]. Its role in cancer is only emerging with documented overexpression in colorectal and oesophageal cancer [53, 54]. Our data showed upregulation of CYBRD1 mRNA in most cell lines tested (MCF7, T-47D, BT-474, ZR-75-30, DU-145) with approximately 2 to 7 -fold induction in TICs (Figure 2A, Supplementary Table S1), and this has been replicated on the protein level for the smaller $25 \mathrm{kDa}$ CYBRD1 isoform in our MCF7 sphere model (Figure 2B). Since molecular mechanism linking CYBRD1 to cancer is missing at this point, we can only speculate that this enzyme could be regulated by members of the HIF family and enhance uptake of non-transferrin bound iron [55].

TFRC gene codes for TFR1 protein, a critical component of the transferrin-bound iron uptake. Elevated expression of TFR1 has been frequently reported in many cancers with possible links to poor prognosis and
A

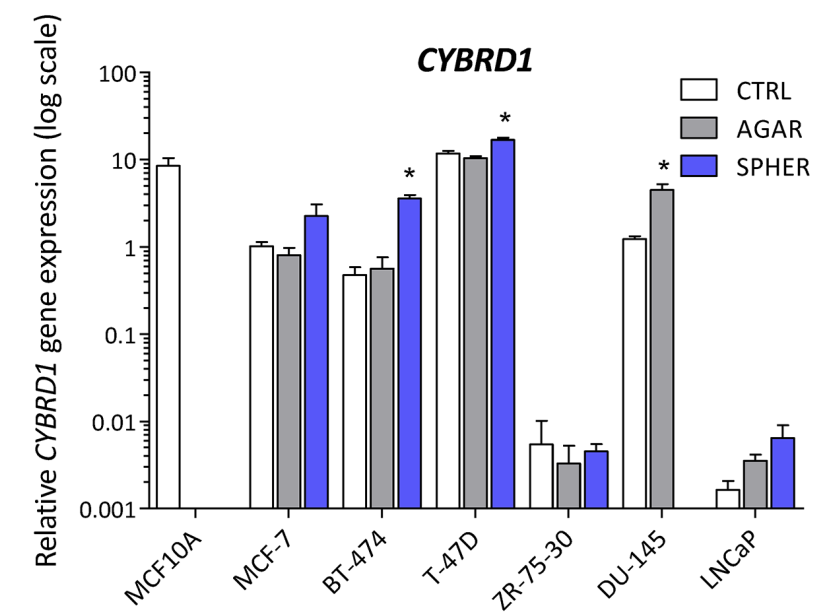

C

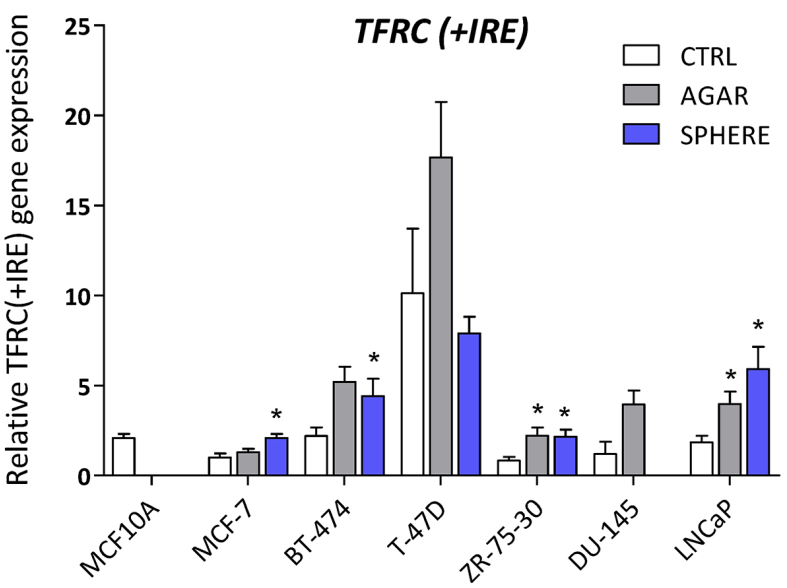

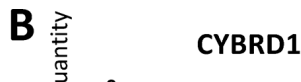
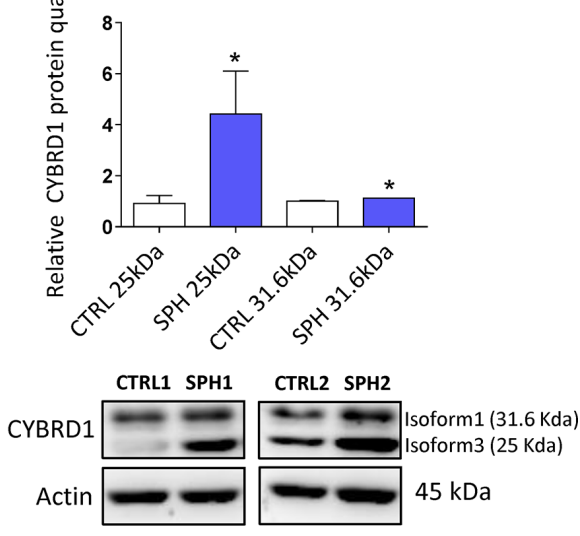

D
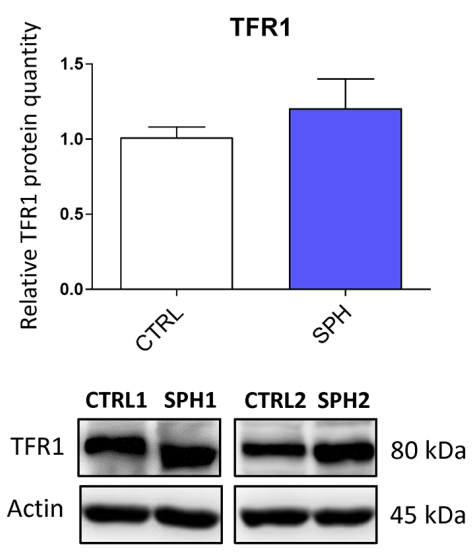

Figure 2: Expression of cytochrome b reductase (CYBRD1) and transferrin receptor 1 (TFR1) participating in iron uptake is higher in tumor-initiating cells (TICs). Expression of the CYBRD1 gene at the mRNA level in breast non-malignant cell line MCF10A, in TICs derived from breast cancer cell lines MCF-7, BT-474, T-47D and ZR-75-30 as well as from prostate cancer cell lines DU-145 and LNCaP has been determined (A) together with protein levels in the MCF-7 cell line (CTRL) and MCF-7 derived spheres (SPH) (B). Similarly, the expression of the TFRC gene at the mRNA (C) level as well as protein level (D) in TICs is documented. Experiments were performed at least in triplicate, standard error is SEM, $p$-values lower than 0.05 are denoted with a star and were calculated by the GenEx software using the unpaired $t$-test and plotted with GraphPad prism software. The protein expression was quantified by the image $\mathrm{J}$ software from 2 to 5 independent samples, standard error is SEM, $p$-values lower than 0.05 are denoted with a star and were calculated and plotted in GraphPad prism, using the unpaired $t$-test. 
acceleration of the disease $[27,53,54,56]$. The expression of this gene is reproducibly elevated in TICs derived by the sphere approach in MCF7, BT-474, LNCaP and ZR-75-30, similarly, this change is also seen with the "agar" approach in BT-474, DU-145, LNCaP, T-47D and ZR-75-30 cells (Figure 2C, Supplementary Table S1). On the protein level, we could see increased levels in spheres derived from MCF7 cells even though not reaching the statistical significance of $p=0.05$ (Figure 2D). Since the expression of TFR1 is regulated by the iron responsive protein/iron responsive element (IRP/IRE) system, we focused on the expression and activity of its components (ACO1, IREB2).

\section{Iron responsive protein/Iron responsive element (IRP/IRE) components are deregulated and show activation of the IRP/IRE binding in TICs}

Aconitase, also known as IRP1 or iron-responsive element-binding protein 1 (IREB1) is encoded by the $A C O 1$ gene. Under normal conditions, this protein functions as a metabolic enzyme participating in the conversion of citrate to isocitrate [57]. However, since ACO1 is an enzyme containing $4 \mathrm{Fe}-4 \mathrm{~S}$ clusters as a cofactor, under iron deprivation, this enzyme dramatically changes its conformation and becomes the IRP1 with high affinity to iron-response elements (IREs) within untranslated regions (UTR) of many genes participating in the uptake and storage of iron, resulting in stabilization (3'UTR) or translation inhibition (5'UTR) of the corresponding mRNA, aiming to increase iron uptake and decrease iron storage $[8,9,58]$. There is emerging evidence about the role of ACO1 in cancer as elevated ACO1 expression suppresses tumor growth in vivo and its level is higher in rectal and hepatocellular carcinoma, while the opposite has been shown in leukemic cells [59-62]. Furthermore, many studies describe higher levels of isocitrate in cancer and cancer stem cells, supporting the role of ACO1 in carcinogenesis [63-66]. In our experimental system, we see approximately 2 -fold increase in ACO1 mRNA in all tested cell lines (Figure 3A, Supplementary Table S1). Moreover, these changes were replicated on the protein level of ACO1, where elevated protein levels are seen in the MCF7 sphere model (Figure 3B). Our data support the notion that ACO1 is upregulated in TICs and may play an important role in their biology.

The second protein binding to IREs is encoded by the IREB2 gene and is also known as IRP2. This protein plays a critical role in the response to iron deprivation and is stabilized under conditions of low iron while under normal iron levels it is rapidly degraded [53, 67-69]. The role of IRP2 in carcinogenesis is only beginning to be appreciated [53, 70-73]. We have found mild, yet significant, upregulation of IREB2 mRNA in all TICs derived by the sphere approach, with an average 2-fold change (Figure 3C, Supplementary Table S1). Contrary to this, we have detected an inverse relationship on the protein level, with downregulation of the IREB2 protein in MCF7 sphere cells (Figure 3D). This, though, has a plausible explanation, as IRP2 is normally degraded when iron level is high enough and its turnover is mediated by ubiquitinylation [74]. Since TICs contain higher levels of LIP, a decrease in IRP2 levels is expected.

We have further analysed the ability of IRP $1 / 2$ to bind the IRE motif and regulate iron uptake and storage by a modified electrophoretic mobility shift assay (EMSA). Our data clearly document activation of the IRP/IRE system showing enhanced binding mostly of the IRP1 to the IRE sequence of human ferritin (Figure 3E), which is in agreement with observed higher iron uptake, predicting that ferritin level would be decreased.

Interestingly, IRP1 activity is regulated by the absence of the assembled FeS cluster as already mentioned. We have thus focused our attention on the components of the mitochondrial FeS cluster biogenesis that show differential expression according to our expression profiling data.

\section{Protein levels of the ATP Binding Cassette Subfamily B Member 10 (ABCB10) and glutaredoxin 5 (GLRX5) participating in mitochondrial FeS cluster assembly are decreased in TICs}

$\mathrm{ABCB} 10$ is a protein belonging to the $\mathrm{ABC}$ transporter family that has mitochondrial localization, participates in the mitochondrial FeS cluster biogenesis and was proposed to mediate protection from reactive oxygen species (ROS) [75]. Its expression has been linked to erythroid heme synthesis; $A b c b 10$ knockout mice suffer from anemia and show mitochondrial iron accumulation [76-78]. Even though our data document rather small (2-fold), yet significant, increase in $A B C B 10$ mRNA expression in all tested cell lines (Figure 4A, Supplementary Table S1), we detected a profound decrease in the ABCB10 protein level in the MCF7 sphere model of TICs (Figure 4B). This suggests that $\mathrm{ABCB} 10$ protein level is probably regulated by a posttranscriptional mechanism. Our data are consistent with the fact that $\mathrm{ABCB} 10$ expression is increased during erythroid differentiation while TICs represent de-differentiated cells with stem cell properties [79] and also comply with the fact that low level of ABCB10 is connected with mitochondrial iron accumulation as seen in Figure 1D.

Glutaredoxin 5 is another component of the mitochondrial FeS cluster machinery. This protein is an important member of the redox balance system, being able to reduce the S-S bonds into free $\mathrm{SH}$ groups; oxidized GLRX5 is then non-enzymatically reduced by glutathione (GSH) [80-82]. This protein is critically 
required for normal mitochondrial FeS cluster biogenesis as its disruption is associated with autosomal recessive pyridoxine-refractory sideroblastic anemia [6, 7, 83-85]. There is a scarce evidence about the role of GLRX5 in carcinogenesis, documenting higher expression of GLRX5 in hepatocellular carcinoma [86]. Interestingly, the expression of this critical component of FeS cluster biogenesis was supressed on the mRNA level in almost all tested cell lines (Figure 4C, Supplementary Table S1) as well as on the protein level in the MCF7 sphere model (Figure 4D). Thus, we can speculate that lower protein levels of GLRX5 may reduce proper FeS cluster biogenesis and since FeS clusters are essential for proper DNA repair and replication $[1,87]$, these alterations could lead to genomic instability of TICs.

\section{Reduced enzymatic activity of FeS cluster containing enzymes, reduced glutathione (GSH) content and increased reactive oxygen species (ROS) levels in TICs}

As we detected activation of the IRP/IRE system and changes in the expression of ABCB10 and GLRX5 that may reduce proper assembly and transport of FeS clusters, we assessed the enzymatic activity of ACO1 (both the cytosolic and mitochondrial form) and also mitochondrial respiratory complex I. Both of these enzymes require FeS clusters for their enzymatic function and lack of properly formed FeS clusters should lead to their lower enzymatic activity. Indeed, our data support this scenario (Figure 5A, 5B). Furthermore,
A

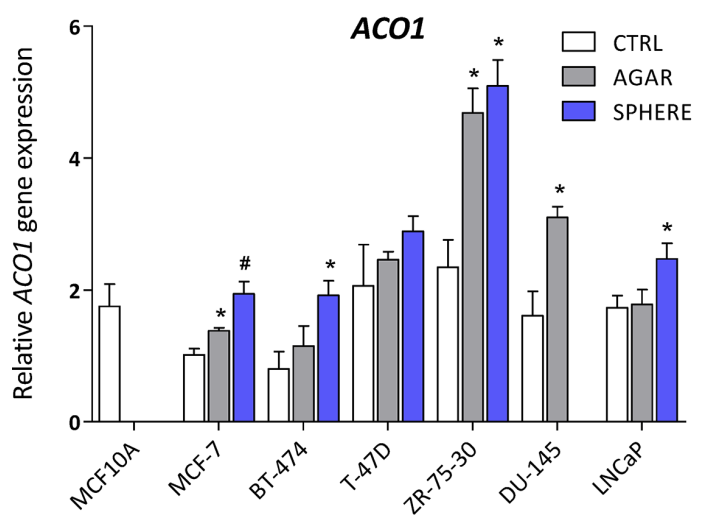

C

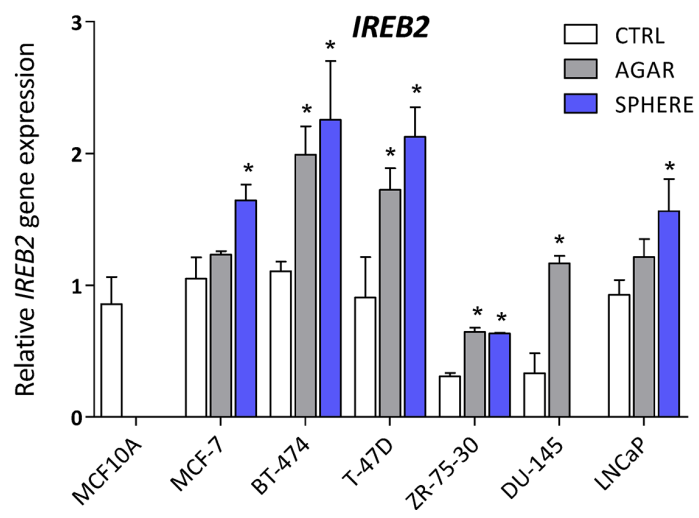

B

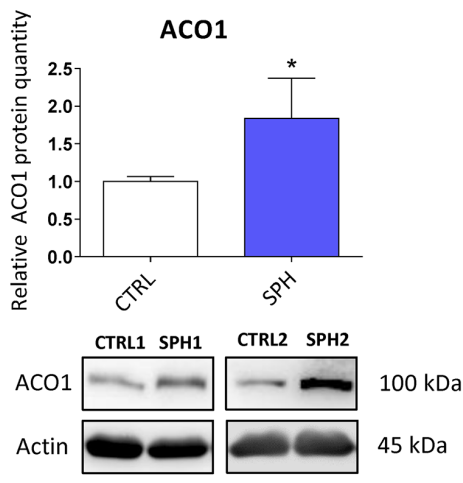

D

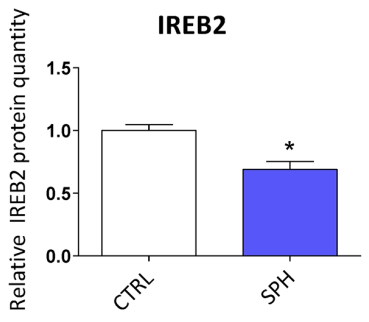

$\mathbf{E}$
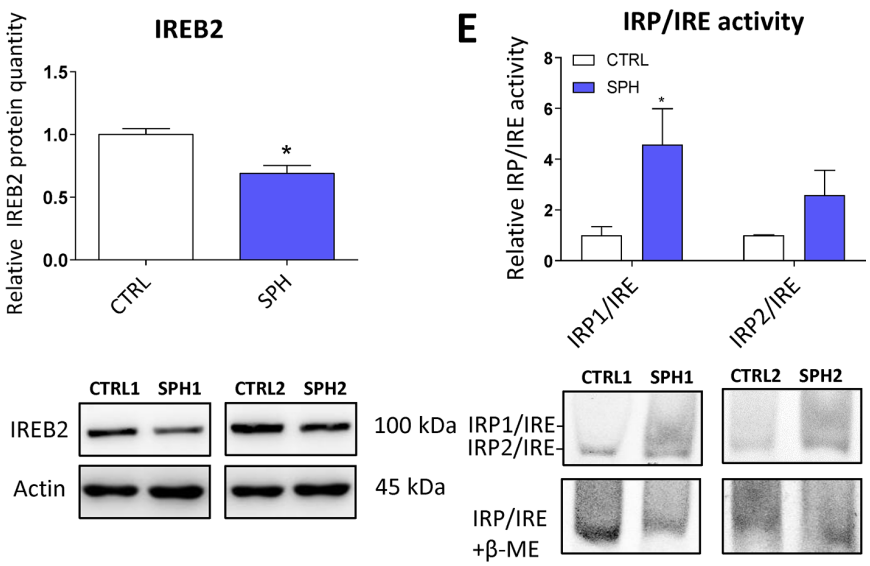

CTRL2 SPH2

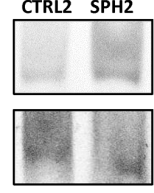

Figure 3: Iron responsive protein/Iron responsive element (IRP/IRE) components are deregulated and show activation of the IRP/IRE binding in tumor-initiating cells (TICs). Expression of the $A C O 1$ gene at the mRNA level in breast non-malignant cell line MCF10A, in TICs derived from breast cancer cell lines MCF-7, BT-474, T-47D and ZR-75-30 as well as from prostate cancer cell lines DU-145 and LNCaP has been determined (A) together with protein levels in the MCF-7 cell line (CTRL) and MCF-7 derived spheres (SPH) (B). Similarly, the expression of the IREB2 gene at the mRNA (C) level as well as protein level (D) in TICs is documented. Experiments were performed at least in triplicate, standard error is SEM, $p$-values lower than 0.05 are denoted with a star and were calculated by the GenEx software using the unpaired $t$-test and plotted with GraphPad prism software. Number sign denotes statistical significance involving Dun-Bonferroni correction. Panel (E) illustrates the IRP/IRE activity measured by the fluorescent EMSA. The protein expression was quantified by the image $\mathrm{J}$ software from 2 to 5 independent samples, standard error is SEM, $p$-values lower than 0.05 are denoted with a star and were calculated and plotted in GraphPad prism, using the unpaired $t$-test. 
as the decreased enzymatic ACO1 activity is linked to oxidative damage [88], we tested levels of reduced GSH and the GSH/GSSG ratio that were significantly reduced in MCF7 spheres (Figure 5C, 5D). The level of ROS, assessed by 2',7'-dichlorofluorescein diacetate (DCF-DA), hydroxyphenylfluorescein (HPF, detecting hydroxyl radical) and mitochondrial superoxide indicator (mitoSOX), was significantly higher in TICs (Figure 5E), as was mitochondrial potential measured by the tetramethylrhodamine, methyl ester (TMRM) staining
(Figure 5F). Higher generation of ROS is possibly due to mitochondrial iron loading and higher labile iron pool inside the cells, supported by the fact that levels of reduced GSH and the GSH/GSSG ratio were significantly lower in TICs, pointing to higher oxidative stress. Since we detected low enzymatic activity ACO1, which is dependent on FeS clusters and inhibited by ROS [88, 89], we further examined cellular response to hypoxia, in particular the expression and activity of hypoxia inducible factors (HIFs) as these are also regulated by iron [90].
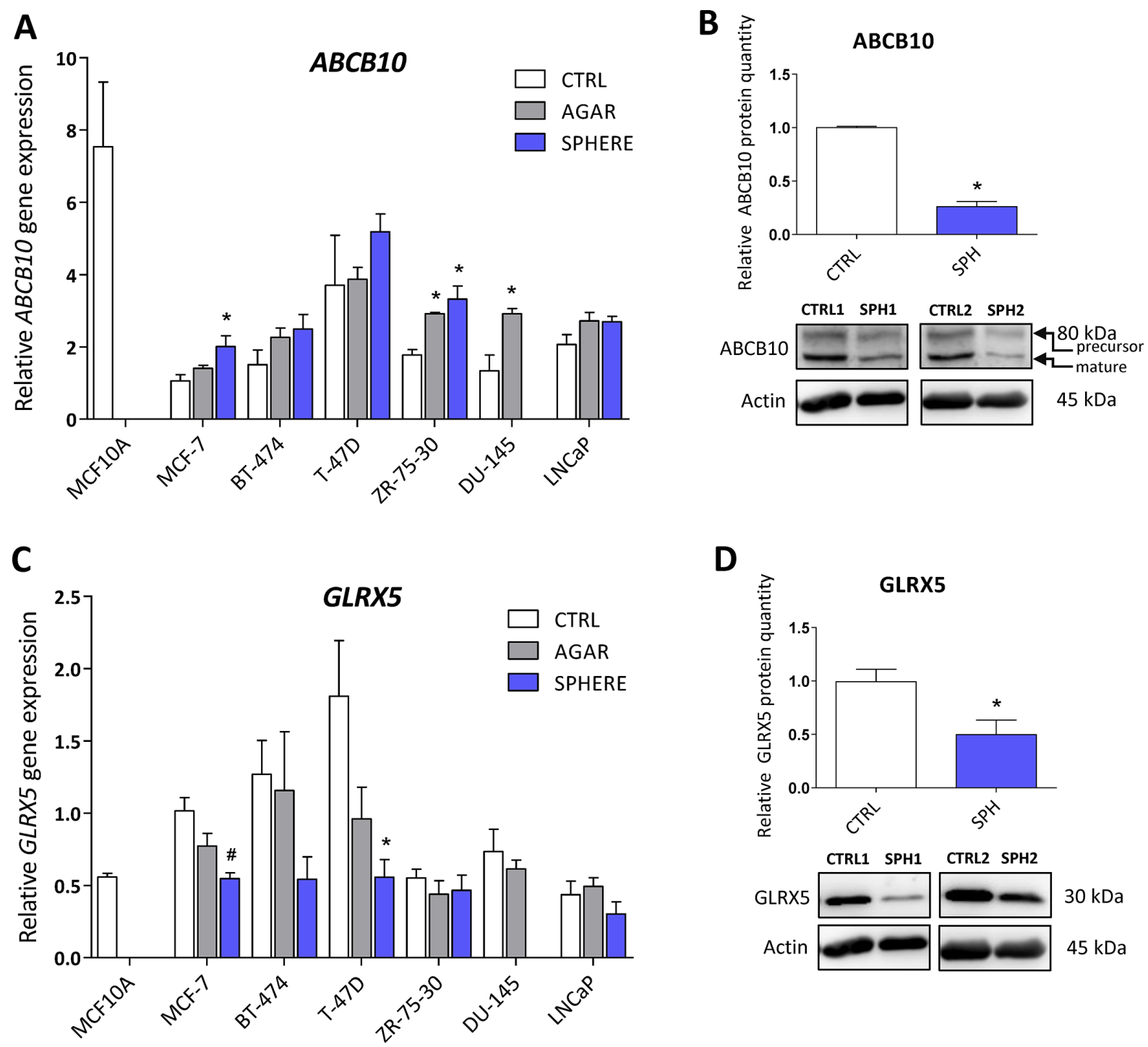

Figure 4: Protein levels of the ATP Binding Cassette Subfamily B Member 10 (ABCB10) and glutaredoxin 5 (GLRX5) participating in mitochondrial FeS cluster assembly are decreased in tumor-initiating cells (TICs). Expression of the $A B C B 10$ gene at the mRNA level in breast non-malignant cell line MCF10A, in TICs derived from breast cancer cell lines MCF-7, BT-474, T-47D and ZR-75-30 as well as from prostate cancer cell lines DU-145 and LNCaP has been determined (A) together with protein levels in the MCF-7 cell line (CTRL) and MCF-7 derived spheres (SPH) (B). Similarly, the expression of the GLRX5 gene at the mRNA (C) level as well as protein level (D) in TICs is documented. Experiments were performed at least in triplicate, standard error is SEM, $p$-values lower than 0.05 are denoted with a star and were calculated by the GenEx software using the unpaired $t$-test and plotted with GraphPad prism software. Number sign denotes statistical significance involving Dun-Bonferroni correction. The protein expression was quantified by the image $\mathrm{J}$ software from 2 to 5 independent samples, standard error is SEM, $p$-values lower than 0.05 are denoted with a star and were calculated and plotted in GraphPad prism, using the unpaired $t$-test. 


\section{Expression of genes related to hypoxia (Endothelial Per-ARNT-Sim Domain Protein 1, $E P A S 1)$, cellular quiescence and extracellular matrix remodelling (Quiescin Sulfhydryl Oxidase 1, QSOX1) is elevated in TICs}

HIFs are normally degraded by the action of prolyl hydroxylases and ubiquitinylation, resulting in proteasomal degradation. Prolyl hydroxylases require iron to carry out
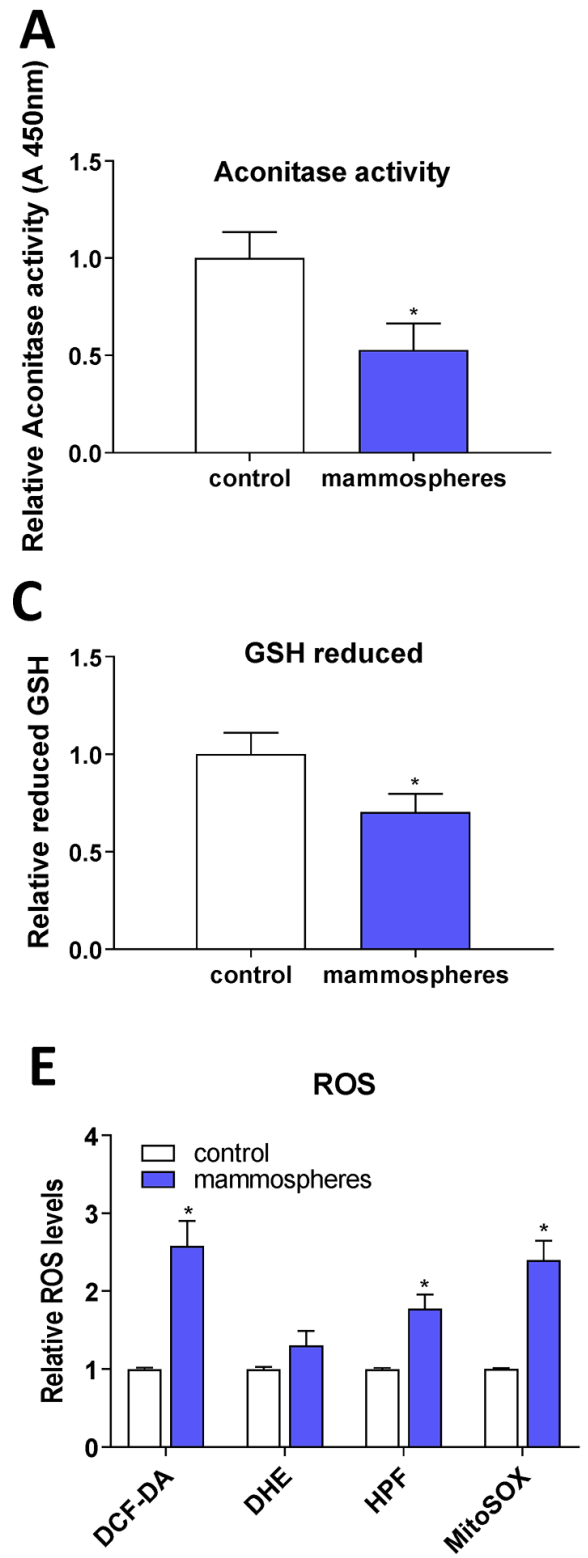

their action, and hypoxia inducible factor 2 (HIF2 $\alpha$ ) has been demonstrated as a direct target of ACO1 that does not contain FeS clusters and functions as an iron sensor, IRP1 [90]. Additionally, ROS have been also shown to stabilize HIF $2 \alpha$ [91]. In accordance with higher IRP1 activity and higher ROS levels in TICs, our profiling data support the role of genes connected with hypoxic response in the phenotype of TICs, in particular the EPAS1 gene coding for the HIF $2 \alpha$ protein. This protein normally regulates

\section{B}
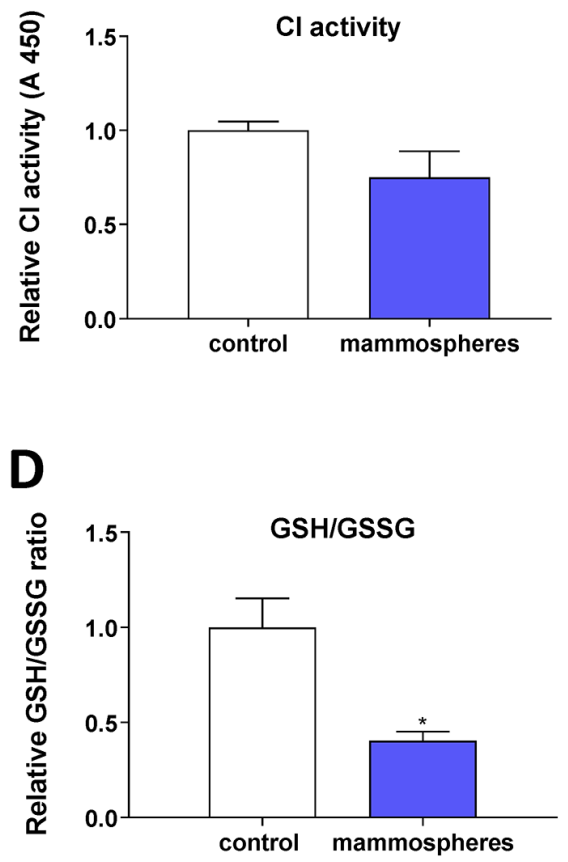

$F$

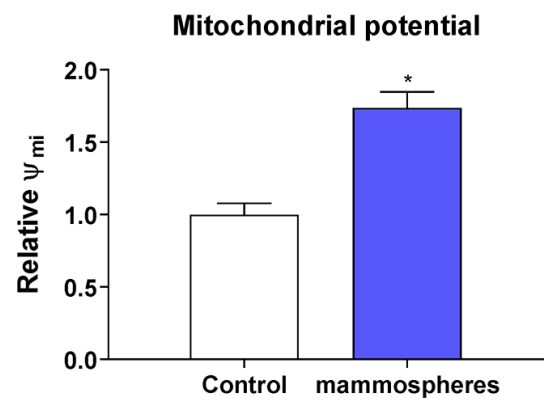

Figure 5: Reduced enzymatic activity of FeS cluster containing enzymes, reduced glutathione (GSH) content and increased reactive oxygen species (ROS) levels in tumor-initiating cells (TICs). Cell cultured under control conditions (control) or in sphere medium (mammospheres) were assessed for the enzymatic activity of aconitase (A) and mitochondrial respiratory complex I (B). Further tests also measured the reduced glutathione (GSH) (C) and the ratio of reduced/oxidized glutathione (GSH/GSSG) ratio (D). Spheres also show higher ROS production (E) measured by 2',7'-dichlorofluorescein diacetate (DCF-DA), dihydroethidium (DHE), hydroxyphenylfluorescein (HPF) and mitochondrial superoxide indicator (mitoSOX). Spheres also show higher mitochondrial potential measured by tetramethylrhodamine methylester (TMRM) (F). Experiments were performed at least in triplicate, standard error is SEM, $p$-values lower than 0.05 are denoted with a star and were calculated by the GraphPad Prism software using the unpaired $t$-test. 
the response of cells to hypoxia but has been also linked to the cancer stem cell phenotype [92]. The actual role of EPAS1 in carcinogenesis has been documented for paragangliomas, pheochromocytomas, bladder cancer, ovarian cancer, and a link to the oxidative phosphorylation and stem cell features has been suggested [24, 40, 93-100]. Interestingly, its expression at the mRNA level is upregulated in spheres derived from MCF7, BT-474, DU-145 and LNCaP spheres, although only DU-145 reached statistical significance (Figure 6A, Supplementary Table S1). These changes were then subsequently confirmed on protein level in MCF7 sphere model (Figure 6B). Thus, HIF $2 \alpha$ could be responsible for metabolic adaptations of TICs and might also be responsible for the observed upregulation of several iron metabolism-related genes such as CYBRD1 or QSOX1 [11, 12].

As pointed above, our analysis also revealed increase in the QSOX1 expression. QSOX1 is a HIF target gene, connected to cellular quiescence and extracellular matrix remodelling [12]. Physiological role of this enzyme includes generation of disulphide bonds accompanied by generation of hydrogen peroxide and it contains the essential for respiratory and vegetative growth (ERV) domain homologous to the yeast Erv1p that is required for maturation of the cytosolic FeS clusters [101-105]. QSOX1 expression is induced in fibroblasts entering quiescence, and its role in cancer is beginning to appear [106] with reports stating that QSOX1 may be a specific marker for the luminal B subtype of breast cancer [107-109]. Its role has been suggested also for pancreatic and lung cancer, and for neuroblastoma [12, 110-112]. QSOX1 can also be involved in inhibition of autophagic flux in cancer cells [113]. Its role in remodelling of extracellular matrix, cell invasion and motility has also been described [114]. The QSOX1 mRNA expression is reproducibly and significantly elevated in spheres derived from MCF7, BT-474, T-47D and also in LNCaP cells (Figure 6C, Supplementary Table S1). The increase in QSOX1 expression was confirmed on the protein level as well (Figure 6D). It is of interest that the highly induced isoform is the $66 \mathrm{kDa}$ variant of this protein with a thus far elusive function. Given the fact that higher expression of QSOX1 may participate in extracellular matrix remodelling and in modulating the ratio between free SH groups and S-S bonds as well as being recognized as an HIF target, we can speculate that QSOX1 may be an important regulator of TICs maintenance and also their migration.

\section{Iron export machinery-related hephaestin $(H E P H)$ is elevated at the mRNA and protein level while the hemochromatosis gene (HFE) related to systemic iron loading is increased only at the mRNA level in TICs}

We have also detected changes in the expression of the $H E P H$ gene, coding for the multi copper oxidase hephaestin, which physiologically helps iron transport from enterocytes [14, 115-117]. Disruption of the $H E P H$ gene results in hypochromic microcytic anemia and retinal iron overload [116, 118, 119]. In relation to cancer, HEPH expression was reduced in colorectal carcinoma and loss of HEPH was associated with more advanced disease [53]. In our sphere model of TICs, the expression of $H E P H$ mRNA was significantly higher in BT-474 and T-47D breast cancer cells while other cell lines also showed increased expression but did not reach statistical significance (Figure 7A, Supplementary Table S1). The $\mathrm{HEPH}$ protein level showed a significant increase in $\mathrm{HEPH}$ protein isoform at $150 \mathrm{kDa}$, while the $100 \mathrm{kDa}$ isoform is decreased in the MCF7 sphere model (Figure 7B). Thus, HEPH role in TICs is probably specific for a particular cell type and individual isoforms and their response to iron and involvement in carcinogenesis might differ.

Interestingly, the $H F E$ gene coding for the hemochromatosis protein was also altered in TICs. This gene and its $\mathrm{C} 282 \mathrm{Y}$ mutant form have long been connected to excessive iron loading in hemochromatic patients. The accumulation of iron caused by mutation in the $H F E$ gene increases the risk of cancer development [53, 120-122]. Unexpectedly, we detected an increase in $H F E$ mRNA level in TICs generated by the sphere approach in MCF7, BT-474, T-47D and DU-145 cells (Figure 7C, Supplementary Table S1). However, on the protein level, no changes were seen in MCF7 sphere model (Figure 7D). Thus, although there seems to be a significant upregulation of HFE mRNA, the lack of response on the protein levels rather suggests that the HFE protein is not linked to the TICs phenotype.

To gain further insight into iron metabolism of TICs, we have assessed the expression of additional important regulators of iron uptake, transfer, storage and export that are known to be regulated on the level of protein rather than on the level of transcription. Since these proteins are regulated on the protein levels they were not picked up by the expression profiling.

\section{Protein levels of regulators related to iron transport (NRAMP2, Natural resistance associated macrophage protein 2 ) and iron storage (ferritin) are decreased while expresssion of proteins participating in non transferrin bound iron (NTBI) uptake (ZIP14, Zinc importer protein 14) and iron export (ferroportin) does not differ in TICs}

First, we examined the expression of solute carrier family 11 member 2 (SLC11A2) coding for a protein known as NRAMP2 or DMT1 (Divalent metal transporter 1). NRAMP2 is known to transport iron from the gut lumen into enterocytes and also participates in the release of transferrin iron from the acidic environment of the lysosomes into cytosol, other studies also suggest 
its role in the non-transferrin bound iron (NTBI) uptake $[16,123,124]$. Its role in carcinogenesis is not well described with possible role in colorectal and oesophageal cancer $[54,61,125]$. Interestingly, the level of SLC11A2 mRNA containing a functional IRE motif (+IRE) measured by the gene profiling, did not dramatically change with exception of the DU-145 cell line; however, the non-IRE variant mRNA seemed significantly upregulated in most cell lines (Supplementary Figure S3A). Yet, NRAMP2 protein levels were significantly reduced in MCF7 sphere model (Figure 8A). This could be an explanation why there is paradoxically higher LIP while cells show activation of
IRP/IRE system, since lack of NRAMP2 would leave the acquired iron locked in the lysosomes, unavailable to be incorporated into the active sites of enzymes and proteins.

Further, we analyzed levels of ferritin at mRNA and protein levels (encoded by FTH and FTL) as ferritin is a major iron storage protein that is capable of binding tremendous amount of iron, storing it and then releasing it when needed. Ferritin is encoded by FTH1 responsible mainly for the ferroxidase activity and also FTL1 which plays a role in iron nucleation and protein stability $[5,126]$. Ferritin has been linked to progression of breast, ovarian, pancreatic and prostate cancer [28, 127-129]. In our data
A

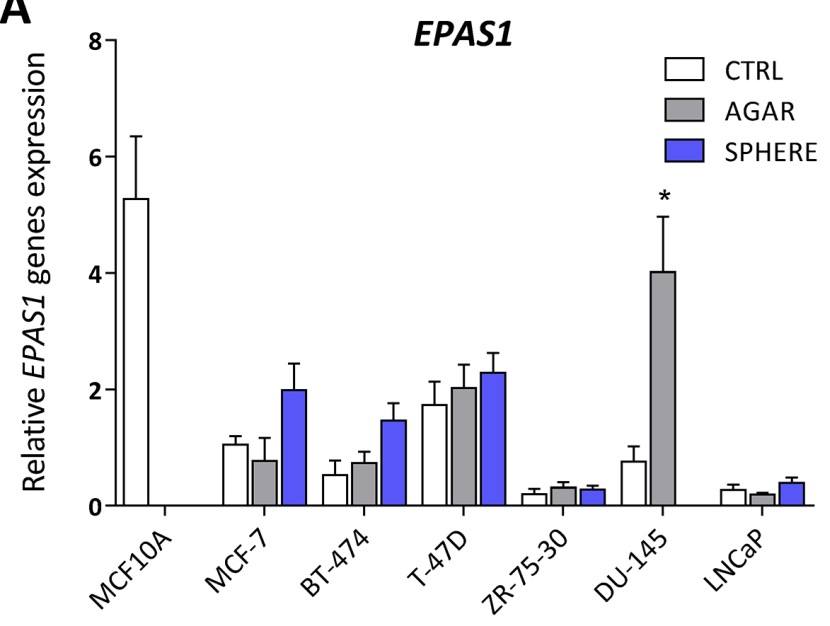

C

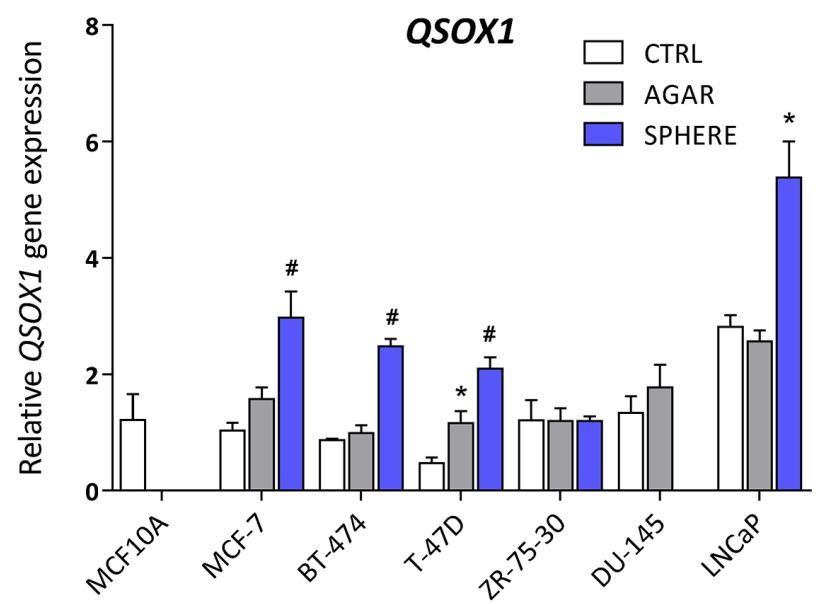

B

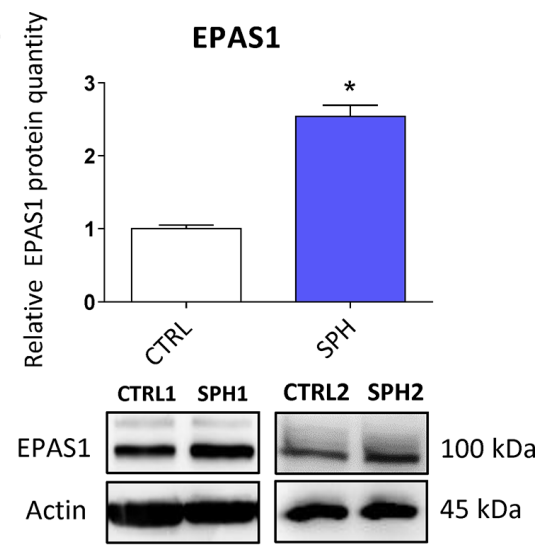

D
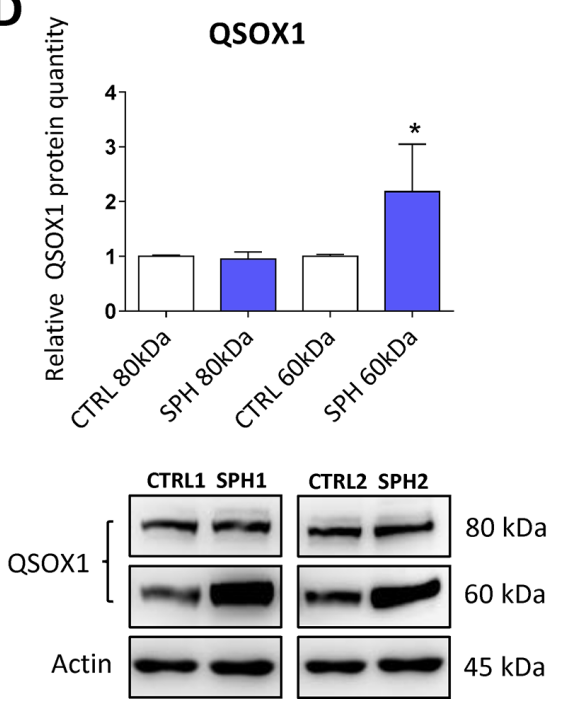

Figure 6: Expression of genes related to hypoxia (Endothelial PAS Domain Protein 1, EPAS1), cellular quiescence and extracellular matrix remodelling (Quiescin Sulfhydryl Oxidase 1, QSOX1) is elevated in tumor-initiating cells (TICs). Expression of the EPAS1 gene at the mRNA level in breast non-malignant cell line MCF10A, in TICs derived from breast cancer cell lines MCF-7, BT-474, T-47D and ZR-75-30 as well as from prostate cancer cell lines DU-145 and LNCaP has been determined (A) together with protein levels in the MCF-7 cell line (CTRL) and MCF-7 derived spheres (SPH) (B). Similarly, the expression of the QSOX1 gene at the mRNA (C) level as well as protein level (D) in TICs is documented. Experiments were performed at least in triplicate, standard error is SEM, $p$-values lower than 0.05 are denoted with a star and were calculated by the GenEx software using the unpaired $t$-test and plotted with GraphPad prism software. Number sign denotes statistical significance involving Dun-Bonferroni correction. The protein expression was quantified by the image $\mathrm{J}$ software from 2 to 5 independent samples, standard error is SEM, $p$-values lower than 0.05 are denoted with a star and were calculated and plotted in GraphPad prism, using the unpaired $t$-test. 
set, there were almost no changes in FTH and a slight increase in FTL mRNA level only in MCF7 and BT-474 (Supplementary Figure S3B), while the protein levels were markedly reduced (Figure $8 \mathrm{~B}$ ). This is in agreement with the activation of the IRP/IRE system implicating that iron storage is reduced and provides another independent validation that the IRP/IRE system activity is increased. Also a reduction of the ferritin levels is in line with a current study suggesting that FTH is a negative regulator of ovarian stem cell expansion [129]
We also analysed expression of an important player in the non-transferrin bound iron (NTBI), the ZIP14 protein encoded by the SLC39A14 gene which has been shown to transport iron $[18,19,130]$. Its role in carcinogenesis is so far unclear with possible role in hepatocellular cancer [131, 132] Interestingly, on the mRNA level we were able to detect an upregulation in most cell lines tested (Supplementary Figure S3C), yet, on the protein level, we did not detect any significant change in by the MCF7 sphere model (Figure 8C) suggesting
A
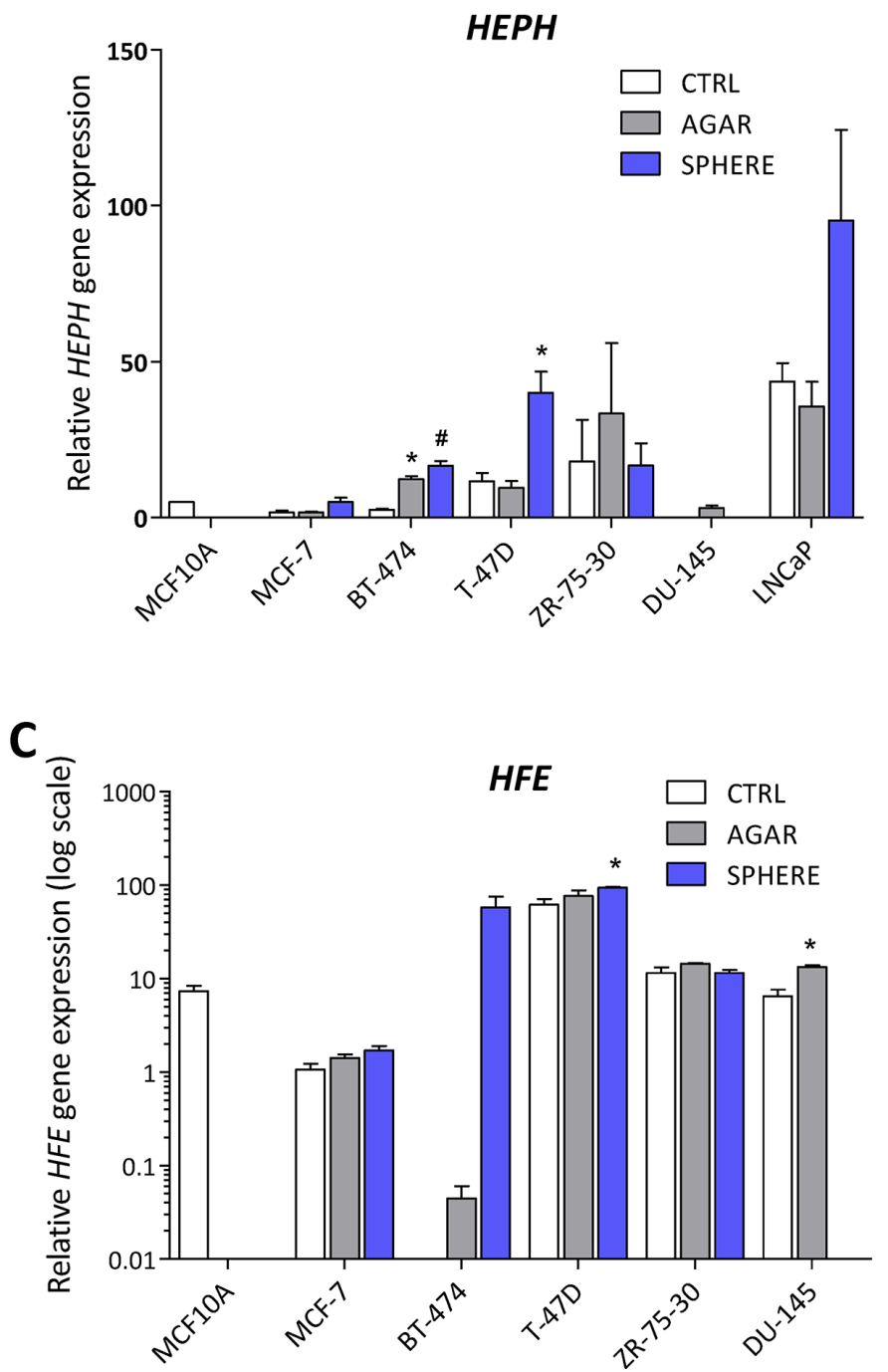

B
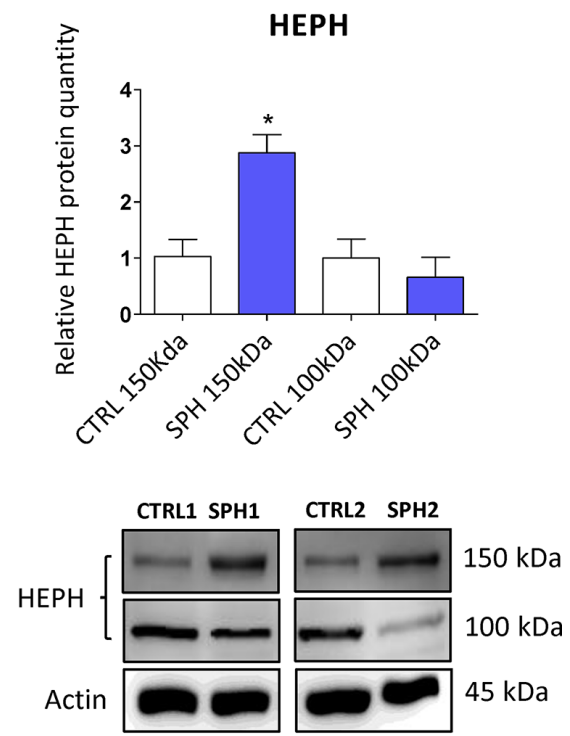

D
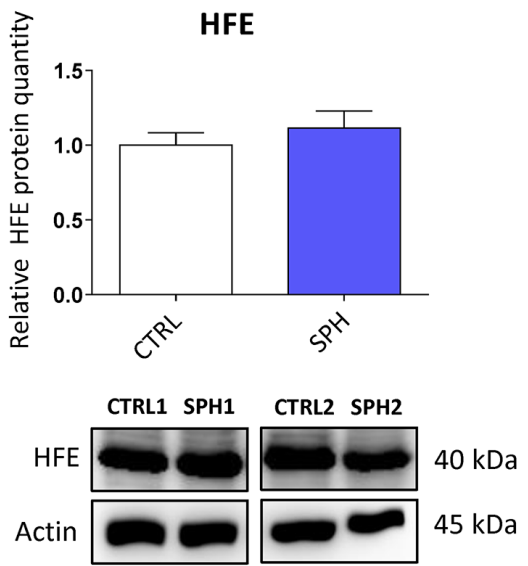

Figure 7: Iron export machinery-related hephaestin $(H E P H)$ and the hemochromatosis gene (HFE) related to systemic iron loading are elevated at the mRNA level but not on the protein level in tumor-initiating cells (TICs). Expression of the HEPH gene at the mRNA level in breast non-malignant cell line MCF10A, in TICs derived from breast cancer cell lines MCF-7, BT474, T-47D and ZR-75-30 as well as from prostate cancer cell lines DU-145 and LNCaP has been determined (A) together with protein levels in the MCF-7 cell line (CTRL) and MCF-7 derived spheres (SPH) (B). Similarly, the expression of the HFE gene at the mRNA (C) level as well as protein level (D) in TICs is documented. Experiments were performed at least in triplicate, standard error is SEM, $p$-values lower than 0.05 are denoted with a star and were calculated by the GenEx software using the unpaired $t$-test and plotted with GraphPad prism software. Number sign denotes statistical significance involving Dun-Bonferroni correction. The protein expression was quantified by the image $\mathrm{J}$ software from 2 to 5 independent samples, standard error is SEM, $p$-values lower than 0.05 are denoted with a star and were calculated and plotted in GraphPad prism, using the unpaired $t$-test. 
that the detected $52 \mathrm{kDa}$ form of ZIP14 is probably not participating in higher iron uptake in TICs.

Additionally, we have examined the expression of the solely know iron exporter, ferroportin, (FPN) encoded by the $S L C 40 A 1$ gene $[15,67,133,134]$. A report connecting lower expression of ferroportin to iron accumulation and cancer progression exists but other research on this topic remain scarce [49]. Our data documented no significant change in the mRNA level in most of the cell lines tested with exception of BT-474 and T-47D where it was increased (Supplementary Figure S3D). However, western blot analysis of its protein level did not show any significant change in MCF7 sphere model (Figure $8 \mathrm{D}$ ). This suggests that a change in iron
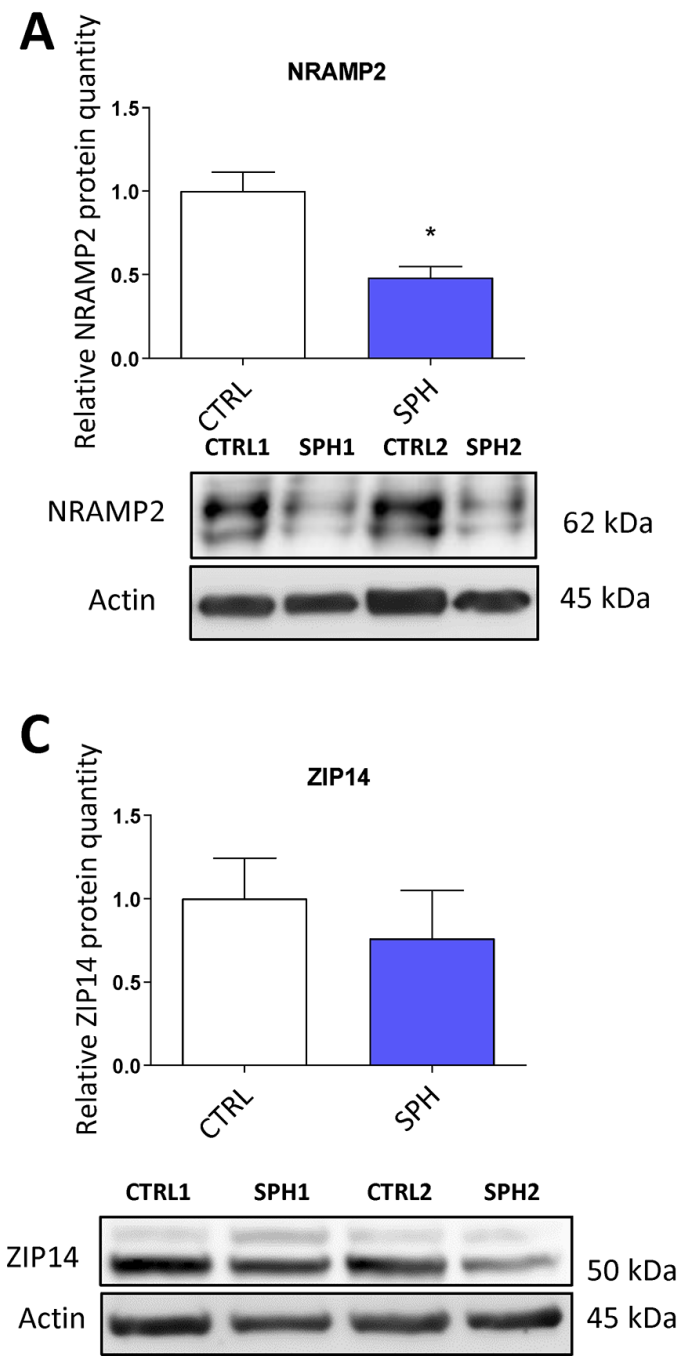

export is not the underlying cause of higher LIP in TICs and the observed changes are rather related to iron uptake and may reflect higher level of improperly assembled FeS clusters.

\section{Expression profiling and protein analysis of the tamoxifen resistant (TAMR) MCF7 cells representing an alternative model of TICs}

To further validate our findings on another in vitro model, we used the tamoxifen resistant MCF7 cells (TAMR) that exhibit features of stem cells (Supplementary Figure S5A) in agreement with published literature [135-137].
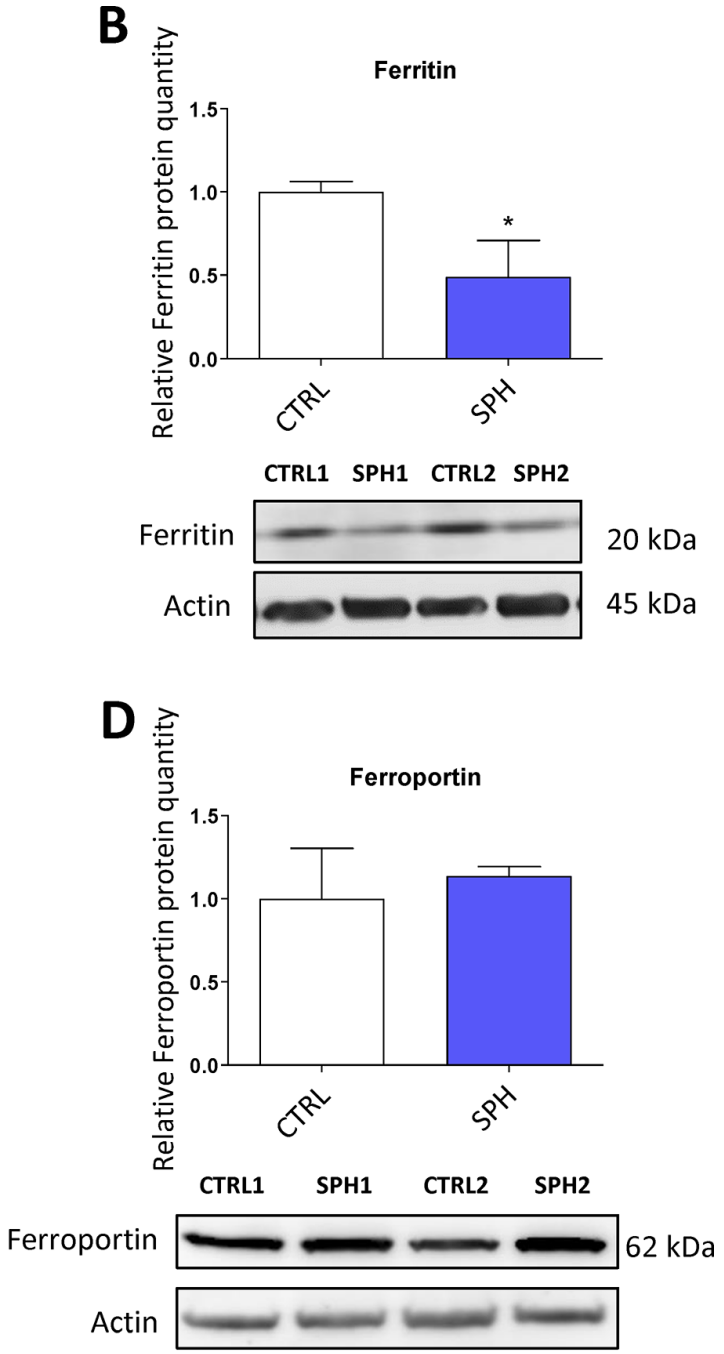

Figure 8: Protein levels of regulators related to iron transport (NRAMP2, Natural resistance associated macrophage protein 2) and iron storage (ferritin) are decreased while expression of proteins participating in non transferrin bound iron (NTBI) uptake (ZIP14, Zinc importer protein 14) and iron export (ferroportin) does not differ in tumorinitiating cells (TICs). Protein levels of NRAMP2 (A), ferritin (B), zinc transporter protein 14 (C) and ferroportin (D) in the MCF-7 cell line (CTRL) and MCF-7 derived spheres (SPH) are shown. The protein expression was quantified by the image J software from 2 to 5 independent samples, standard error is SEM, $p$-values lower than 0.05 are denoted with a star and were calculated and plotted in GraphPad prism, using the unpaired $t$-test. 
These cells mostly recapitulated findings seen in TICs represented by the MCF7 spheres. They show higher levels of LIP, higher ROS, reduced GSH (data not shown) and identical regulation of ABCB10, ACO1, GLRX5, EPAS1, 100kDa isoform of HEPH, IREB2, SLC39A14, SLC40A1 and QSOX1 with statistically significant changes on the mRNA and protein level (Supplementary Figure S5B, Supplementary Figure S6) pointing to high similarity in terms of iron gene signature. Yet, we have detected different regulation in protein levels of $150 \mathrm{kDa}$ isoform of HEPH, TFRC, Ferritin and SLC11A2 (Supplementary Figure S6). These differences might be related to the presence of tamoxifen, an agent that is known to generate ROS, resulting in adaptation to permanent oxidative stress. One of the possible mechanism might be upregulation of ferritin which is able to inactivate free iron by its ferroxidase activity [138].

Furthermore, unlike MCF7 spheres, TAMR cells show higher SLC11A2 (DMT1) levels and no change in TFR1 levels. Yet, it might just be a different mechanism how to acquire iron, which seem to be more dependent on TFR1 in spheres, while TAMR cells probably use more of the non-transferrin bound iron via the SLC11A2, both converging on higher iron uptake as suggested by Miller et al [49]. Thus, the alternative model of TAMR cells confirmed majority of changes seen in the model of MCF7 spheres and supports the importance of iron in the biology of TICs.

\section{Analysis of the iron metabolism-related genes in leukemia-initiating cells (LICs) from leukemic mice in vivo}

To further expand our findings from an in vitro conditions to an in vivo conditions, we used a murine model of acute promyelocytic leukemia (APL) that allows for identification and isolation of LICs, based on the depletion cocktail-, c-kit+, and CD34+ expression profile. Non-LICs from leukemic mice were characterized by depletion cocktail-, c-kit-, and CD34- expression profile and the expression of lactoferrin (Ltf) that is highly induced in the differentiated cells [139]. Unfortunately, we were not able to determine expression on the level of protein since the number of cells that are obtained after sorting is very low for some sorted populations and western blot of several proteins is technically unfeasible.

We detected statistically significant upregulation of Glrx5 and Tfrc mRNA between leukemic CD34/c-kit- (non-LICs) and CD34+/c-kit+ (LICs) populations as well as significant differences in the expression of Cybrd1 and Qsoxl between CD34+/c-kit+ (LICs) populations of normal and leukemic mice (Supplementary Figure S2A, Supplementary Table S2). Furthermore, expression of Aco1, Epas1, Glrx5, Hfe, Ireb2 and Tfrc mRNA was significantly altered between the CD34-/ckit- (non-LICs) populations of normal and leukemic cells
(Supplementary Figure S2A, Supplementary Table S2). Comparing the sorted CD34+/c-kit+(LICs) population to whole bone marrow, we could see a similar picture, which is statistically significant upregulation in Epas 1 and Glrx 5 and changes in the $A b c b 10$ and Qsox 1 expression that were very close to significance (Supplementary Figure S2B, Supplementary Table S2). Thus, we did see significant changes in expression of iron metabolism-related genes supporting the evidence that iron uptake in these cells is higher and their FeS cluster metabolism and hypoxia related genes show higher expression.

\section{Principal component analysis (PCA) based on the expression of selected iron-metabolism related genes is able to distinguish tumor- initiating cells (TICs) in vitro and leukemia- initiating cells (LICs) in the acute promyelocytic leukemia (APL) mouse model}

In order to define whether the expression of the identified differential iron metabolism-related gene signature is able to distinguish TICs from non-TICs, we performed the PCA analysis based on the expression of gene signature identified by the expression profiling consisting of Aco1, Abcb10, Cybrd1, Epas1, Glrx5, Heph, Hfe, Ireb2, Qsox 1, Tfrc genes. The PCA clearly documents that sphere samples are clustered separately from the control adherent cancer cells in all of the tested cell lines (Figure 9). This is further documented for the TAMR cells as well (Figure 9). Furthermore, the PCA analysis with similar gene set (excluding Heph), applied on an in vivo APL mouse model of leukemia-initiating cells is also able to easily distinguish the population using similar gene set with exclusion of Heph is also able to easily distinguish the population of LICs (CD34+/c-kit+) from non-LICs (CD34-/c-kit-), thus replicating our findings in cell lines (Supplementary Figure S4). Thus, Thus, although we obtained we obtained our iron metabolism related gene signature in breast cancer TICs, and we applied it to a leukemia cells, we were clearly able to distinguish the LICs from non-LICs as well.

\section{Summary}

In this report, we examined the role of iron in the biology of TICs. We show that TICs exhibit marked alterations in the iron metabolism and handling and also show differential gene expression of the iron metabolismrelated genes, thus pointing to the importance of iron in the biology of TICs.

To gain a more detailed knowledge about the iron metabolism in TICs, we assessed many aspects related to iron metabolism. We show that TICs contain higher labile iron pool (LIP), in other words these cells contain more loosely bound iron. Free iron is known to generate ROS via the Fenton and Haber-Weiss reactions. Thus, 
in agreement with higher LIP in TICs, we detected higher level of hydroxyl radicals and also higher level of mitochondrial superoxide, in line with the observed accumulation of iron in mitochondria.

Since oxidative stress and labile iron pool are known to regulate the function of the iron responsive proteins (IRPs), we assessed their expression and function. Our data show that especially IRP1 known also as ACO1 is activated and binds to its cognate element, IRE. This results in higher iron uptake via TFRC and CYBRD1 and lower levels of ferritin, the major intracellular iron storage protein. As ACO1 requires FeS clusters for its enzymatic function and its IRP1 function is connected with the absence of FeS clusters, we looked into the expression of the FeS cluster assembly components. Our data clearly show that there is low expression of ABCB10 and GLRX5 proteins, both of which are located in mitochondria. Together with low amount of GSH which is required for normal $\mathrm{FeS}$ cluster biosynthesis, our data suggest that FeS cluster assembly is inefficient in TICs, resulting in an increase of IRP1 activity of ACO1 and possibly leading to iron accumulation in mitochondria due to low $\mathrm{ABCB} 10$ levels. This is further supported by lower enzymatic activity of proteins requiring FeS clusters for their catalytic activity such as mitochondrial respiratory complex I and the above mentioned ACO1. Furthermore, low levels of properly assembled FeS clusters may also underlie higher sensitivity of TICs to iron withdrawal that was observed and predispose them for genetic instability and very high plasticity.

Interestingly, ACO1 that does not contain FeS clusters shows high IRP1 activity and stabilizes the EPAS1 mRNA coding for the HIF2 $\alpha$ [90]. In addition, protein stability of HIF $2 \alpha$ is enhanced by ROS [91]. In agreement with this, we have detected higher levels of HIF $2 \alpha$ in TICs, possibly connecting it with activation of HIF targets (DCYTB1, QSOX1). The activation of QSOX1 which is connected with extracellular remodelling and cellular quiescence might be an important step regulating cellular migration and invasion. All the above mentioned changes are depicted in summarizing Figure 10.

Other iron metabolism related proteins participating in iron export (HEPH, ferroportin), iron trafficking and non-transferrin-bound iron (NRAMP2, ZIP14) and iron
MCF-7

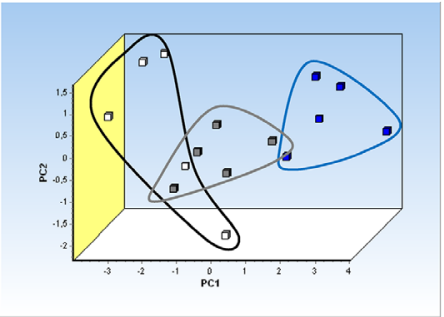

ZR-75-30

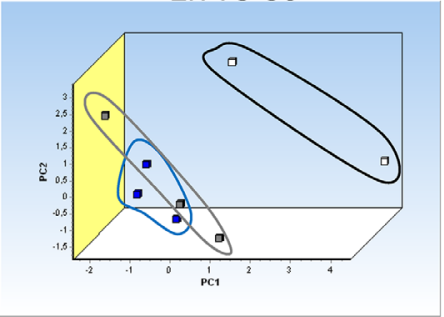

BT-474

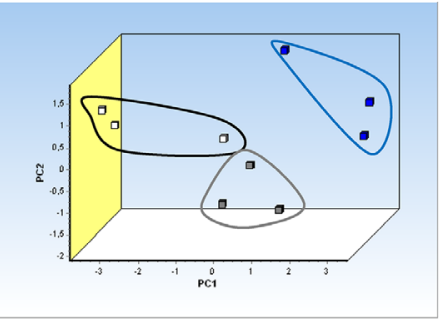

DU-145

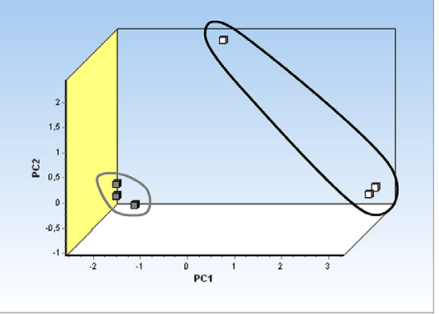

$\mathrm{T}-47 \mathrm{D}$

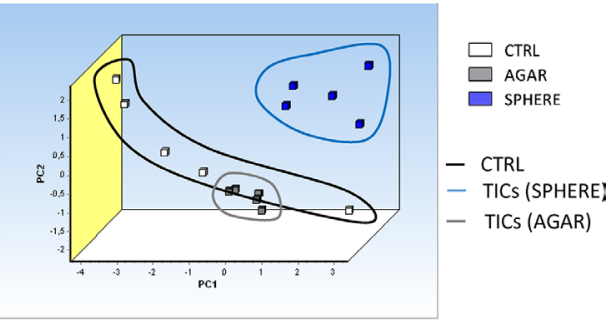

LNCaP

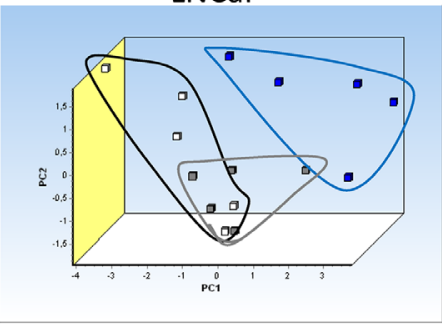

MCF7 TAMR

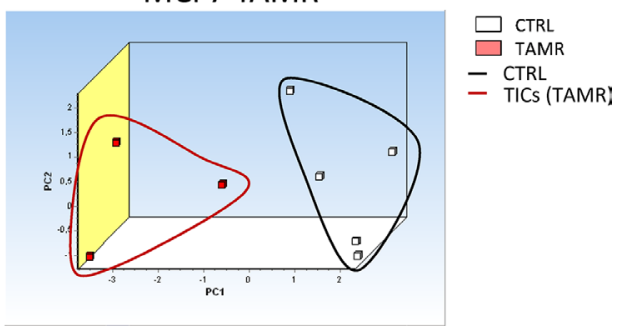

Figure 9: Principal component analysis (PCA) discriminates tumor-initiating cells (TICs) from cancer cells based on gene expression of the selected iron metabolism-related genes (Aco1, Abcb10, Cybrd1, Epas1, Glrx5, Heph, Hfe, Ireb2, Qsox1 and Tfrc). Principal component analysis (PCA) based on selected iron metabolism-related genes was run on malignant breast MCF-7, BT-474, T-47D, ZR-75-30 and malignant prostate DU-145 as well as LNCaP cell lines using the GenEx software which was also used for plotting the PCA. White squares depict control conditions, grey show agar conditions, blue boxes show sphere conditions and red boxes show TAMR cells. Individual clusters were also highlighted with corresponding lines using identical colors. 
storage (ferritin) were examined. We detected higher levels of the HEPH mRNA and higher levels of HEPH $150 \mathrm{~K}$ da variant, no changes in ferroportin and ZIP14 while there is a clear downregulation of ferritin and NRAMP2. Thus, in agreement with the activation of the IRP/IRE system, ferritin level is suppressed and the involvement of NRAMP2 and ZIP14 in the acquisition of iron in TICs is unlikely.

Lastly, our work identified a specific iron metabolism-related gene signature differentially expressed in TICs (ABCB10, ACO1, CYBRD1, EPAS1, GLRX5, HEPH, HFE, IREB2, QSOX1 and TFRC). The principal component analysis based on this signature is able to distinguish not only TICs in vitro (TICs growing as spheres and also TICs represented by the tamoxifen resistant MCF7 cells) but also LICs in vivo, thus confirming the importance of iron metabolism in their phenotype. Further research focusing on the role of the differentially expressed iron metabolism-related proteins in TICs biology and cancer resistance is warranted and may be of clinical importance. Studies examining the role of combination therapy using anti TICs drugs in combination with iron chelators might pave the path to a novel treatments in the future.

\section{MATERIALS AND METHODS}

\section{Tissue culture and sphere generation}

Cells were routinely cultivated in Dulbecco's Modified Eagle Medium (DMEM) (BT-474, DU145, MCF7, T-47D, ZR-75-30 cells) or Roswell Park Memorial Institute medium (RPMI1640) (LNCaP cells) supplemented with $10 \%$ fetal bovine serum (FBS), $10 \mathrm{mM}$ 4-(2-hydroxyethyl)-1-piperazineethanesulfonic acid (HEPES) and $2 \mathrm{mM}$ glutamine. MCF-10A cells were cultivated in DMEM/F12 with 5\% horse serum and antibiotics, supplemented with $0.1 \mathrm{ng} / \mathrm{ml}$ cholera toxin, $20 \mathrm{ng} / \mathrm{ml}$ epidermal growth factor (EGF), 0.5 $\mu \mathrm{g} / \mathrm{ml}$ hydrocortisone, $1 \mathrm{mg} / \mathrm{ml}$ insulin. All cells were obtained either directly from ATCC or from prof. Lopez (Griffith University, Australia). For the generation of spheres, advanced DMEM/F12 or RPMI1640 medium supplemented with $5 \%$ of proliferation supplement, $20 \mathrm{ng} /$
Cancer cell

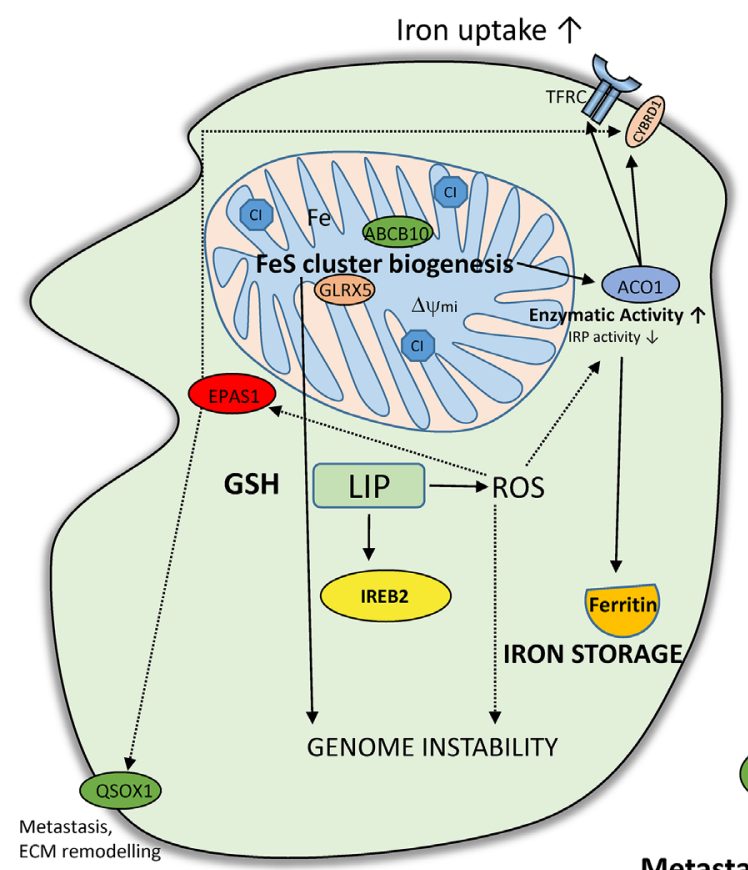

Tumour-initiating cancer cell (TIC)

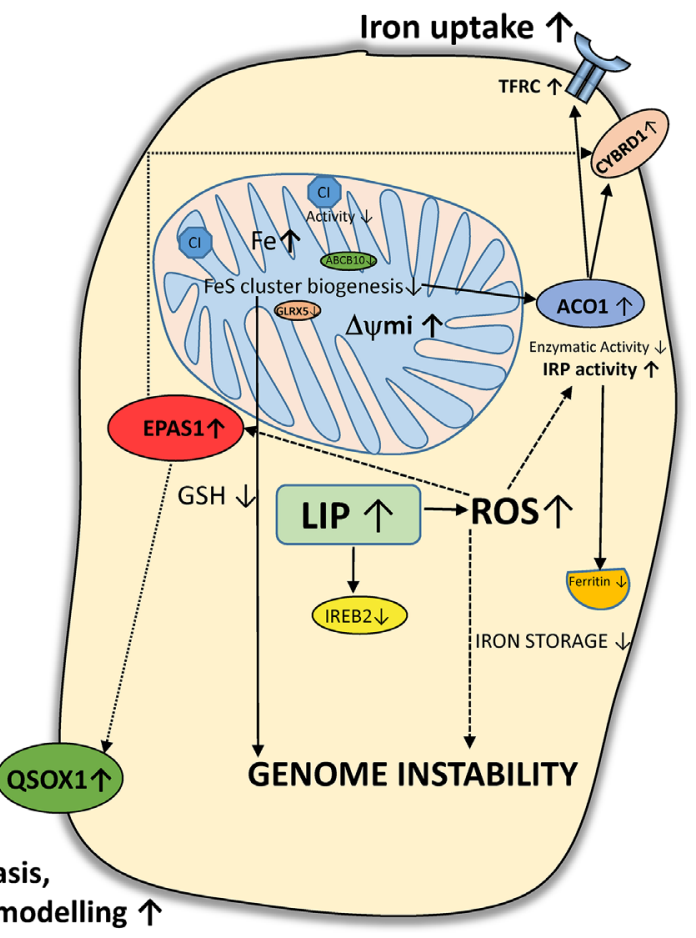

Figure 10: Putative scheme depicting changes in iron metabolism of tumor-initiating cells (TICs). TICs show higher levels of labile iron pool (LIP) and subsequently higher reactive oxygen species (ROS) which in connection with lower Fes cluster biogenesis (lower expression of ABCB10 and GLRX5) leading to accumulation of iron in mitochondria and possibly affecting genome stability and increasing plasticity of these cells. Alterations in the FeS cluster assembly lead to reduced activity of ACO1/IRP1 as well as mitochondrial respiratory complex I. The IRP binding activity of ACO1 is elevated resulting in higher TFRC and lower ferritin levels. Furthermore, TICs show an increase in the protein level of of EPAS1/ HIF2A connected with higher iron uptake (CYBRD1, TFRC) as well as with the extracellular matrix remodelling and redox balance equilibrium via the expression of QSOX1. On the other hand, reduced glutathione (GSH) is lower in TICs and these cells seem to be in a more pro-oxidative state and contain lower protein levels of IREB2/IRP2 likely reflecting increased LIP. 
$\mathrm{ml}$ EGF, $5 \mathrm{ng} / \mathrm{ml}$ fibroblast growth factor (FGF), $4 \mu \mathrm{g} / \mathrm{ml}$ heparin, $10 \mathrm{mM}$ HEPES, $1 \mathrm{mM}$ glutamine and penicillin/ streptomycin antibiotics was used. Control medium contained 5\% FBS instead of proliferation supplement and was supplemented with $1 \mathrm{mM}$ glutamine, $10 \mathrm{mM}$ HEPES and penicillin/streptomycin. Cells generated by the agar approach were cultivated in normal serum containing medium but on a plastic ware coated with $1 \%$ agarose.

\section{RNA isolation and quality determination}

RNA was isolated by the method using RNAzol RT according to manufacturer's instructions. Briefly, cells were collected, spun and lysed in $500 \mu \mathrm{l}$ of RNAzol. The lysate was then mixed with $200 \mu$ l of RNAse-free water, vortexed and incubated for $10 \mathrm{~min}$ at room temperature (RT), and spun at $12,500 \times \mathrm{g}$ for $15 \mathrm{~min}$. The supernatant was then mixed with 4-bromoanisole, incubated for $10 \mathrm{~min}$ and spun at $12,500 \times \mathrm{g}$ for $10 \mathrm{~min}$. The supernatant was next precipitated with equal volume of isopropanol, spun at $4^{\circ} \mathrm{C}$ at $14,000 \times \mathrm{g}$ for $15 \mathrm{~min}$, washed twice with $80 \%$ ethanol, dried and dissolved in RNAse free water $(20 \mu \mathrm{l})$. RNA quantity was measured with the Nanodrop spectrophotometer (ND-1000, Thermo Scientific), and each RNA integrity was measured with the Agilent 2100 Bionalyser (Agilent Technologies).

\section{cDNA synthesis and sample preparation for the Fluidigm qPCR}

RNA quality of the used samples was determined by the RNA integrity number score (RIN between 8-10), and cDNA was reverse-transcribed by the Maxima $\mathrm{H}$ minus reverse transcriptase kit (Thermo Scientific) using $400 \mathrm{ng}$ total RNA as a template and oligo-dT as primers, according to manufacturer's instructions.

\section{Fluidigm qPCR}

Primer design was performed with Primer BLAST. All assays were designed to span at least one intron and/ or to have one primer covering an exon/exon boundary. Each sample was pre-amplified with mix of all primer pairs for 18 cycles. The reaction contained $5 \mu \mathrm{l}$ of iQ Supermix (Bio-Rad), $2 \mu 1$ of diluted cDNA, $1.25 \mu \mathrm{l}$ of pre-amplification primer mix in final concentration 25 $\mathrm{nM}$ and $1.25 \mu \mathrm{l}$ of water. Temperature profile was $95^{\circ} \mathrm{C}$ for $60 \mathrm{~s}$ and 18 cycles of $95^{\circ} \mathrm{C}$ for $15 \mathrm{~s}$ and $4 \mathrm{~min}$ at $60^{\circ} \mathrm{C}$. qPCR was performed using the high-throughput platform BioMark HD System (Fluidigm) with 96.96 Dynamic ArrayIFC for gene expression. $5 \mu \mathrm{L}$ of sample pre-mix contained $1 \mu \mathrm{l}$ of $20 \mathrm{x}$ diluted preamplified cDNA, $2.5 \mu \mathrm{l}$ of SsoFast EvaGreen Supermix (Bio-Rad), $0.25 \mu \mathrm{l}$ of $20 \mathrm{x}$ SG sample loading reagent (Fluidigm) and $1.25 \mu \mathrm{l}$ of water. Five $\mu$ l of assay pre-mix contained $2 \mu \mathrm{l}$ of $10 \mu \mathrm{M}$ primer/probe assays, $2.5 \mu \mathrm{l}$ of $2 \times$ assay loading reagent (Fluidigm) and $0.5 \mu \mathrm{l}$ of water. Thermal conditions for qPCR were: $98^{\circ} \mathrm{C}$ for $3 \mathrm{~min}, 35$ cycles of $98^{\circ} \mathrm{C}$ for $5 \mathrm{~s}$ and $60^{\circ} \mathrm{C}$ for $5 \mathrm{~s}$. Raw data were subtracted from the gDNA control and efficiencies of individual assays were calculated from the serial dilutions of a mixed cDNA sample. Assays with insufficient efficacy or very high $\mathrm{Cq}$ values $(>25)$ were excluded from the analysis. The actual analysis was done via the GenEx software version 6 , and the missing values were replaced by the mean of average value calculated from the whole group. Reference genes for normalization were identified by Normfinder; data were normalized to several reference genes (GAPDH, POLR2A, RPLPO, HPRT1 and TBP). The data were assessed for statistical analysis by using the unpaired $t$-test via GenEx, with the $p$-value $<0.05$ was considered statistically significant and results with the Dun-Bonferroni correction are presented as well.

\section{Western blot analysis}

Protein expression was assessed by a standard western blot assay. Briefly, cells were washed with phosphate-buffered saline (PBS) and lysed directly on a Petri dish in $1 \mathrm{x}$ cell lysis buffer supplemented with protease and phosphatase inhibitors. Protein concentration was measured via the bicinchinonic acid (BCA) method, and 50-80 $\mu \mathrm{g}$ of total protein was loaded in each well of the SDS-PAGE gel. Gels were then separated according to standard procedure at 20 $\mathrm{mA}$ per well, washed in $1 \times$ towbin buffer and blotted onto a nitrocellulose membrane via Xcell blotting module (Invitrogen) at constant voltage $(35 \mathrm{~V})$ for $2 \mathrm{~h}$. Membranes were then blocked with 5\% non-fat milk for $1 \mathrm{~h}$, washed and incubated in 5\% bovine serum albumin (BSA)/Tris-buffered saline (TBS)/0,1\% Tween-20 with primary antibodies against ABCB10 (ThermoScientific \#PA5-30468, dil. 1:1000), ACO1 (ThermoScientific \#PA5-27824, dil. 1:1000), CYBRD1 (Bioss \#bs-8297R, dil. 1:1000), EPAS1 (ThermoScientific \#PA116510, dil. 1:1000), GLRX5 (Bioss \#bs-13395R, dil. 1:1000), HEPH (Bioss \#bs-15458R, dil. 1:1000), HFE (Bioss \#bs-12335R, dil. 1:1000), IREB2 (ThermoScientific \#PA116544, 1:500), QSOX1 (Sigma \#SAB2700031, dil. 1:1000), TFRC (ThermoScientific \#13-6800, dil. 1:2500), SLC39A14 (Abcam \#ab191199, dil. 1:2000), SLC40A1 (Bioss \#bs-4906R, dil. 1:1000) SLC11A2 (Cell Signalling \#15083, dil. 1:1000), Ferritin (Abcam \#ab75973, dil. 1:1000), Actin (Thermoscientific \#MA515739-HRP, dil. 1:2000), Tubulin (Abcam \#ab4742, dil. 1:5000) overnight. Membranes were then washed three times with $1 \times \mathrm{TBS} / 0.1 \%$ Tween-20, incubated with corresponding horseradish peroxidase (HRP) conjugated antibody in $1 \%$ milk $1 \times \mathrm{TBS} / 0.1 \%$ Tween-20 for $1 \mathrm{~h}$. Then the membranes were again washed three times with $1 \times \mathrm{TBS} / 0.1 \%$ Tween-20 and incubated with either Clarity ECL (Biorad) or Sirius ECL substrate 
(Advansta), and luminescence was assessed with LAS4000.

\section{Labile iron pool (LIP) measurement}

A method based on calcein dequenching has been used [52]. Briefly, cells were incubated with $250 \mathrm{nM}$ calcein acetoxymethylester-(calcein-AM) for $30 \mathrm{~min}$ in medium supplemented with $1 \%$ BSA but without serum and sodium bicarbonate. Samples were then washed twice with Hanks Balanced Salt Solution (HBSS). 10,000 cells were added to each well of a 96-well plate, and fluorescence measurement started at the excitation wavelength of $468 \mathrm{~nm}$, emission wavelength of $517 \mathrm{~nm}$, after initial $5 \mathrm{~min}$ measurement. $100 \mu \mathrm{M}$ salicylaldehyde isonicotinoyl hydrazone (SIH) was added and the fluorescence was recorded after $2 \mathrm{~min}$.

\section{${ }^{55} \mathrm{Fe}$ uptake measurement}

Cells were dissociated by using the cell dissociating buffer (1\% BSA, $1 \mathrm{mM}$ EDTA, $1 \mathrm{mM}$ EGTA), washed twice with the reaction buffer $(50 \mathrm{mM}$ HEPES (pH 7.4), $94 \mathrm{mM} \mathrm{NaCl}, 7.4 \mathrm{mM} \mathrm{KCl}, 0.74 \mathrm{mM}$ $\mathrm{MgCl}_{2}, 5 \mathrm{mM}$ D-Glucose) and divided into Eppendorf tubes to contain 1 million of cells per sample with total volume of $200 \mu \mathrm{l} .1 \mu \mathrm{l}$ containing $1 \mu \mathrm{Ci}$ of ${ }^{55} \mathrm{Fe}$ in complex with citrate $(1: 10)$ was added. Cells were then incubated at $37^{\circ} \mathrm{C}$ for 90 minutes with occasional mixing and after the incubation, samples were cooled on ice. Background binding was determined by addition of $1 \mu \mathrm{Ci}$ of ${ }^{55} \mathrm{Fe}$ to the cells followed by immediate cooling. Samples were then washed $5 \mathrm{x}$ with the reaction buffer, re-suspended in $100 \mu \mathrm{l}$ of water and added to $5 \mathrm{ml}$ of scintillation fluid. Samples were then measured on a scintillation counter and background corrected. Relative uptake was then calculated by comparing MCF7 spheres vs. control cells.

\section{${ }^{55} \mathrm{Fe}$ subcellular localization}

Cells were incubated with $50 \mathrm{nM}{ }^{55} \mathrm{Fe}$ complexed with citrate (1:10) for $72 \mathrm{hrs}$. Cells were then centrifuged and washed with $1 \mathrm{x}$ reaction buffer used in iron uptake experiments (50 mM HEPES (pH 7.4), $94 \mathrm{mM} \mathrm{NaCl}$, $7.4 \mathrm{mM} \mathrm{KCl}, 0.74 \mathrm{mM} \mathrm{MgCl}, 5 \mathrm{mM}$ D-Glucose). Cells were counted and diluted with STE buffer $(250 \mathrm{mM}$ sucrose, $10 \mathrm{mM}$ TRIS, $1 \mathrm{mM}$ EDTA) to a concentration of 4 milion cells per $1 \mathrm{ml}$ STE. Cells were then disrupted as shown by Schmitt et al. to retain functional mitochondria [140]. Cellular homogenate was then spun at $800 \times \mathrm{g}$ for 5 minutes to collect nuclei then spun at $3000 \times \mathrm{g}$ for 5 minutes and resulting supernatant was spun at $9,000 \times \mathrm{g}$ for 10 minutes to gain mitochondrial fraction. Protein content in each faction was determined by the BCA-based assay and $20 \mu \mathrm{g}$ of proteins was then measured on a scintillation counter and background corrected.

\section{Cellular viability assays (Cell Titer-Glo, Cell Titer-Fluor)}

Cell viability assays were performed according to manufacturer's instructions (Promega, G7570 and G6080). Briefly, cells for the Cell Titer-Glow assay were seeded at of 5,000 cells per well into white luminescence plates, and after incubation with SIH, the Cell Titer-Glow reagent equal to the volume of medium was added and luminescence was captured using the TECAN 200 PRO reader. For the Cell Titer-Fluor assay, cells were seeded similarly but into a black fluorescent 96 well plates. After incubation with SIH, cells were incubated with fluorogenic peptideglycylphenylalanyl-aminofluorocoumarin and its fluorescence recorded at the excitation wavelength of 400 $\mathrm{nm}$ and emission wavelength of $505 \mathrm{~nm}$ using using Tecan infinity 200 PRO.

\section{Aconitase activity measurement}

The Sigma aconitase activity assay (MAK051) was used. Absorbance was assessed at $450 \mathrm{~nm}$ according to manufacturer's instruction using Tecan infinity 200 PRO. The obtained values were corrected for the background activity of lysates without substrate and normalized to protein content assessed by the BCA method. Relative values compared to control cells were then plotted via Graphpad prism.

\section{Assessment of the IRE/IRP system activity via fluorescent EMSA}

Cells were collected by centrifugation at $300 \times \mathrm{g}, 5$ minutes, washed once with PBS a lysed in buffer containing $10 \mathrm{mM}$ HEPES (pH 7.4), $3 \mathrm{mM}$ $\mathrm{MgCl}_{2}, 40 \mathrm{mM} \mathrm{KCl}, 1 \mathrm{mM}$ DTT and $0.2 \%$ NP-40. Proteins were then quantified by the BCA method and $60 \mu \mathrm{g}$ of protein lysate was then incubated with $4 \mu \mathrm{M}$ of the Cy5 labeled IRE probe containing the $1 \times$ IRE sequence from the human FTH gene (Cy5UCGUCGGGGUUUCCUGCUUCAACAGUGCUUGGACGGAACCGGCGCU) in $24 \mathrm{mM}$ HEPES, $60 \mathrm{mM} \mathrm{KCl}$, $5 \%$ Glycerol, $0.004 \mathrm{U} / \mu 1 \mathrm{RNAsin}$, plus or minus $2 \% \beta$-ME in a total volume of $20 \mu \mathrm{l}$ for 20 minutes, then $2 \mu \mathrm{l}$ of heparin [141, 142] was added and incubated for another 10 minutes. Consequently, $2.4 \mu 1$ of $10 \times$ loading dye was added and the reaction mixture was loaded onto 3-20\% AA gel in $1 \times$ TBE. Electrophoresis was then run at $70 \mathrm{~V}$ for 30 minutes, followed by $120 \mathrm{~V}$ until the blue dye reached the bottom of the gel. The gel was then visualized by the Typhoon instrument.

\section{Mitochondrial respiratory complex I activity}

Abcam mitochondrial respiratory complex I (CI) activity assay (ab109721) was used, utilizing immuno-capture 
of $\mathrm{CI}$ and then colorimetric reaction measuring its activity via absorbance increase at $450 \mathrm{~nm}$ according to manufacturer's instructions. Relative values compared to control cells were then plotted via Graphpad prism.

\section{Reduced glutathione (GSH) and reduced/ oxidized glutathione (GSH/GSSG) ratio measurement}

A fluorescence-based kit for determination of GSH and GSH/GSSG ratio was used according to manufacturer's instructions (BioVision). Briefly, cells were spun, washed with PBS and lysed in cell lysis buffer. $1 \mu \mathrm{g}$ of total protein was loaded into 25 microliters of assay buffer in a 384-well plate. 25 microliters of the glutathione assay mixture (GAM) or total glutathione assay mixture (TGAM) mixture was added to samples, and reduced or oxidized glutathione standard curves plotted. Fluorescence was measured at the excitation wavelength of $480 \mathrm{~nm}$ and emission wavelength at 520 nm using Tecan infinity 200 PRO.

\section{Assessment of mitochondrial membrane potential $(\Delta \Psi \mathrm{mi})$ and reactive oxygen species (ROS)}

To assess ROS or $\triangle \Psi \mathrm{mi}$, spheres and control cells were dissociated by cell dissociation buffer to obtain single cell suspension and incubated with fluorescent probes for $15 \mathrm{~min}$. $\Delta \Psi \mathrm{mi}$ was assessed with $50 \mathrm{nM}$ tetramethylrhodamine methyl ester (TMRM), and ROS were evaluated using $5 \mu \mathrm{M}$ dichlorofluorescein diacetate (DCF-DA), $2.5 \mu \mathrm{M}$ dihydroethidium (DHE), $5 \mu \mathrm{M}$ hydroxyphenyl fluorescein (HPF) or $2.5 \mu \mathrm{M}$ MitoSOX. After incubation, cells were spun down and resuspended in PBS. Fluorescence was measured by flow cytometer (BD FACS Calibur) and expressed as a mean fluorescence intensity. Data were normalized to control cells and plotted via Graphpad Prism.

\section{Preparation of an acute promyelocytic leukemia (APL) in vivo model and isolation of LICs}

An in vivo model of murine APL was prepared as previously described [139]. Briefly, leukemic spleen cells from hMRP8 PML-RAR transgenic mice were transplanted by retro-orbital injection into sub-lethally irradiated 12 week old FVB/N mice. Spleen cells from either leukemic or wild-type control mice were sorted using an Influx cell sorter based on expression of the following cell surface markers: Scal (clone D7; Biolegend), CD45/B220 (RA3-6B2; Biolegend), CD19 (MB19-1; Biolegend), CD3 (145-2C11, Biolegend) antigens, all pacific blue conjugated (omitting Gr1 antibodies from the usual depletion cocktail). The depletion cocktail-negative cells were then separated using antibodies against c-kit conjugated with allophycocyanin (clone 2B8; Biolegend) and CD34 conjugated with fluorescein isothiocyanate (RAM34; eBioscience). LICs from leukemic mice were characterized by depletion cocktail-, c-kit+, and CD34+ expression. Non-LICs from leukemic mice mice were characterized by depletion cocktail-, c-kit-, and CD34- expression. Counterpart nonleukemic populations were isolated from wild-type control mice.

\section{CONFLICTS OF INTEREST}

No competing financial interests exist

\section{GRANT SUPPORT}

This work has been supported by the GACR grant no. 13-28830S and the Kellner Family Foundation to J.T., and GACR grant no. 15-03796S to M. A-J, as well as by the by the Ministry of Education, Youth and Sports of CR within the LQ1604 National Sustainability Program II (Project BIOCEV-FAR) and by the project BIOCEV (CZ.1.05/1.1.00/02.0109).

\section{REFERENCES}

1. Paul VD, Lill R. Biogenesis of cytosolic and nuclear ironsulfur proteins and their role in genome stability. Biochim Biophys Acta. 2015; 1853:1528-1539.

2. Sheftel AD, Mason AB, Ponka P.The long history of iron in the Universe and in health and disease. Biochim Biophys Acta. 2012; 1820:161-187.

3. Hentze MW, Muckenthaler MU, Andrews NC. Balancing acts; molecular control of mammalian iron metabolism. Cell. 2004; 117:285-297.

4. McKie AT, Barrow D, Latunde-Dada GO, Rolfs A, Sager G, Mudaly E, Mudaly M, Richardson C, Barlow D, Bomford A, Peters TJ, Raja KB, Shirali S et al. An ironregulated ferric reductase associated with the absorption of dietary iron. Science. 2001; 291:1755-1759.

5. Torti FM, Torti SV. Regulation of ferritin genes and protein. Blood. 2002; 99:3505-3516.

6. Rouault TA, Tong WH. Iron-sulfur cluster biogenesis and human disease. Trends Genet. 2008; 24:398-407.

7. Ye H, Jeong SY, Ghosh MC, Kovtunovych G, Silvestri L, Ortillo D, Uchida N, Tisdale J, Camaschella C, Rouault TA. Glutaredoxin 5 deficiency causes sideroblastic anemia by specifically impairing heme biosynthesis and depleting cytosolic iron in human erythroblasts. J Clin Invest. 2010; 120:1749-1761.

8. Hentze MW, Kuhn LC. Molecular control of vertebrate iron metabolism: mRNA-based regulatory circuits operated by iron, nitric oxide, and oxidative stress. Proc Natl Acad Sci USA. 1996; 93:8175-8182. 
9. Cairo G, Pietrangelo A. Iron regulatory proteins in pathobiology. Biochem J. 2000; 352 Pt 2:241-250.

10. Peyssonnaux C, Zinkernagel AS, Schuepbach RA, Rankin E, Vaulont S, Haase VH, Nizet V, Johnson RS. Regulation of iron homeostasis by the hypoxia-inducible transcription factors (HIFs). J Clin Invest. 2007; 117:1926-1932.

11. Shah YM, Matsubara T, Ito S, Yim SH, Gonzalez FJ. Intestinal hypoxia-inducible transcription factors are essential for iron absorption following iron deficiency. Cell Metab. 2009; 9:152-164.

12. Shi CY, Fan Y, Liu B, Lou WH. HIF1 contributes to hypoxia-induced pancreatic cancer cells invasion via promoting QSOX1 expression. Cell Physiol Biochem. 2013; 32:561-568.

13. Roy CN, Enns CA. Iron homeostasis: new tales from the crypt. Blood. 2000; 96:4020-4027.

14. Petrak J, Vyoral D. Hephaestin - a ferroxidase of cellular iron export. Int J Biochem Cell Biol. 2005; 37:1173-1178.

15. Abboud S, Haile DJ. A novel mammalian iron-regulated protein involved in intracellular iron metabolism. J Biol Chem. 2000; 275:19906-19912.

16. Lam-Yuk-Tseung S, Govoni G, Forbes J, Gros P. Iron transport by NRAMP2/DMT1: $\mathrm{pH}$ regulation of transport by two histidines in transmembrane domain 6. Blood. 2003; 101:3699-3707.

17. Gunshin H, Mackenzie B, Berger UV, Gunshin Y, Romero MF, Boron WF, Nussberger S, Gollan JL, Hediger MA. Cloning and characterization of a mammalian proton-coupled metal- ion transporter. Nature. 1997; 388:482-488.

18. Liuzzi JP, Aydemir F, Nam H, Knutson MD, Cousins RJ. Zip14 (Slc39a14) mediates non-transferrin-bound iron uptake into cells. Proc Natl Acad Sci USA. 2006; 103:13612-13617.

19. Nam H, Wang CY, Zhang L, Zhang W, Hojyo S, Fukada T, Knutson MD. ZIP14 and DMT1 in the liver, pancreas, and heart are differentially regulated by iron deficiency and overload: implications for tissue iron uptake in iron-related disorders. Haematologica. 2013; 98:1049-1057.

20. Beutler E, Gelbart T, West C, Lee P, Adams M, Blackstone R, Pockros P, Kosty M, Venditti CP, Phatak P, Seese NK, Gerhard G, Chorney M. Molecular diagnosis of hereditary hemochromatosis. Blood. 1996; 88:647a

21. Richardson DR, Kalinowski DS, Lau S, Jansson PJ, Lovejoy DB. Cancer cell iron metabolism and the development of potent iron chelators as anti-tumour agents. Biochim Biophys Acta. 2009; 1790:702-717.

22. Merlot AM, Kalinowski DS, Richardson DR Novel chelators for cancer treatment: where are we now? Antioxid Redox Signal. 2013; 18:973-1006.

23. Lui GY, Kovacevic Z, Richardson V, Merlot AM, Kalinowski DS, Richardson DR. Targeting cancer by binding iron: Dissecting cellular signaling pathways. Oncotarget. 2015; 6:18748-18779. doi: 10.18632/oncotarget.4349.
24. Koh MY, Lemos R, Jr., Liu X, Powis G. The hypoxiaassociated factor switches cells from HIF-1alpha- to HIF-2alpha-dependent signaling promoting stem cell characteristics, aggressive tumor growth and invasion. Cancer Res. 2011; 71:4015-4027.

25. Deugnier Y, Turlin B. Iron and hepatocellular carcinoma. J Gastroenterol Hepatol. 2001; 16:491-494.

26. Sempos CT. Iron and colorectal cancer. Nutr.Rev. 2001; 59:344-345.

27. Habashy HO, Powe DG, Staka CM, Rakha EA, Ball G, Green AR, Aleskandarany M, Paish EC, Douglas MR, Nicholson RI, Ellis IO, Gee JM. Transferrin receptor (CD71) is a marker of poor prognosis in breast cancer and can predict response to tamoxifen. Breast Cancer Res Treat. 2009; 119:283-293.

28. Richardson DR. Iron and neoplasia: Serum transferrin receptor and ferritin in prostate cancer. J Lab Clin Med. 2004; 144:173-175.

29. Torti SV, Torti FM. Cellular iron metabolism in prognosis and therapy of breast cancer. Crit Rev Oncog. 2013; 18:435-448.

30. Torti SV, Torti FM. Iron and cancer: more ore to be mined. Nat Rev Cancer. 2013; 13:342-355.

31. Song S, Christova T, Perusini S, Alizadeh S, Bao RY, Miller BW, Hurren R, Jitkova Y, Gronda M, Isaac M, Joseph B, Subramaniam R, Aman A, et al. Wnt inhibitor screen reveals iron dependence of beta-catenin signaling in cancers. Cancer Res. 2011; 71:7628-7639.

32. Apseloff G. Therapeutic uses of gallium nitrate: past, present, and future. Am J Ther. 1999; 6:327-339.

33. Chitambar CR, Antholine WE. Iron-targeting antitumor activity of gallium compounds and novel insights into triapine((R))-metal complexes. Antioxid Redox Signal. 2013; 18:956-972.

34. Einhorn L. Gallium nitrate in the treatment of bladder cancer. Semin.Oncol. 2003; 30:34-41.

35. Seligman PA, Moran PL, Schleicher RB, Crawford ED. Treatment with gallium nitrate: evidence for interference with iron metabolism in vivo. Am J Hematol. 1992; 41:232-240.

36. Klonisch T, Wiechec E, Hombach-Klonisch S, Ande SR, Wesselborg S, Schulze-Osthoff K, Los M. Cancer stem cell markers in common cancers - therapeutic implications. Trends Mol Med. 2008; 14:450-460.

37. Fillmore CM, Kuperwasser C. Human breast cancer cell lines contain stem-like cells that self-renew, give rise to phenotypically diverse progeny and survive chemotherapy. Breast Cancer Res. 2008; 10:R25.

38. Meacham CE, Morrison SJ. Tumour heterogeneity and cancer cell plasticity. Nature. 2013; 501:328-337.

39. Semenza GL. The hypoxic tumor microenvironment: A driving force for breast cancer progression. Biochim Biophys Acta. 2016; 1863:382-391.

40. Peng G, Liu Y. Hypoxia-inducible factors in cancer stem cells and inflammation. Trends Pharmacol Sci. 2015; $36: 374-383$. 
41. Marhold M, Tomasich E, El-Gazzar A, Heller G, Spittler A, Horvat R, Krainer M, Horak P. HIF1alpha Regulates mTOR Signaling and Viability of Prostate Cancer Stem Cells. Mol Cancer Res. 2015; 13:556-564.

42. Peitzsch C, Perrin R, Hill RP, Dubrovska A, Kurth I. Hypoxia as a biomarker for radioresistant cancer stem cells. Int J Radiat Biol. 2014; 90:636-652.

43. Kida A, Kahn M. Hypoxia selects for a quiescent, CML stem/leukemia initiating-like population dependent on CBP/ catenin transcription. Curr Mol Pharmacol. 2013; 6:204-210.

44. Prigione A, Rohwer N, Hoffmann S, Mlody B, Drews K, Bukowiecki R, Blumlein K, Wanker EE, Ralser M, Cramer T, Adjaye J. HIF1alpha modulates cell fate reprogramming through early glycolytic shift and upregulation of PDK1-3 and PKM2. Stem Cells. 2014; 32:364-376.

45. Rouault-Pierre K, Lopez-Onieva L, Foster K, AnjosAfonso F, Lamrissi-Garcia I, Serrano-Sanchez M, Mitter R, Ivanovic Z, de VH, Gribben J, Taussig D, Rezvani HR, Mazurier F, et al. HIF-2alpha protects human hematopoietic stem/progenitors and acute myeloid leukemic cells from apoptosis induced by endoplasmic reticulum stress. Cell Stem Cell. 2013; 13:549-563.

46. Marie-Egyptienne DT, Lohse I, Hill RP. Cancer stem cells, the epithelial to mesenchymal transition (EMT) and radioresistance: potential role of hypoxia. Cancer Lett. 2013; 341:63-72.

47. Silvan U, Diez-Torre A, Arluzea J, Andrade R, Silio M, Arechaga J. Hypoxia and pluripotency in embryonic and embryonal carcinoma stem cell biology. Differentiation. 2009; 78:159-168.

48. Das B, Tsuchida R, Malkin D, Koren G, Baruchel S, Yeger H. Hypoxia enhances tumor stemness by increasing the invasive and tumorigenic side population fraction. Stem Cells. 2008; 26:1818-1830.

49. Miller LD, Coffman LG, Chou JW, Black MA, Bergh J, D'Agostino R, Jr., Torti SV, Torti FM. An iron regulatory gene signature predicts outcome in breast cancer. Cancer Res. 2011; 71:6728-6737.

50. Yan B, Stantic M, Zobalova R, Bezawork-Geleta A, Stapelberg M, Stursa J, Prokopova K, Dong L, Neuzil J. Mitochondrially targeted vitamin E succinate efficiently kills breast tumour-initiating cells in a complex IIdependent manner. BMC Cancer. 2015; 15:401

51. Chen SF, Chang YC, Nieh S, Liu CL, Yang CY, Lin YS. Nonadhesive culture system as a model of rapid sphere formation with cancer stem cell properties. PLoS ONE. 2012; 7:e31864

52. Epsztejn S, Kakhlon O, Glickstein H, Breuer W, Cabantchik I. Fluorescence analysis of the labile iron pool of mammalian cells. Anal Biochem. 1997; 248:31-40.

53. Brookes MJ, Hughes S, Turner FE, Reynolds G, Sharma N, Ismail T, Berx G, McKie AT, Hotchin N, Anderson GJ, Iqbal T, Tselepis C. Modulation of iron transport proteins in human colorectal carcinogenesis. Gut. 2006; 55:1449-1460.
54. Boult J, Roberts K, Brookes MJ, Hughes S, Bury JP, Cross SS, Anderson GJ, Spychal R, Iqbal T, Tselepis C. Overexpression of cellular iron import proteins is associated with malignant progression of esophageal adenocarcinoma. Clin Cancer Res. 2008; 14:379-387.

55. Luo X, Hill M, Johnson A, Latunde-Dada GO. Modulation of Dcytb (Cybrd 1) expression and function by iron, dehydroascorbate and Hif-2alpha in cultured cells. Biochim Biophys Acta. 2014; 1840:106-112.

56. Beckman LE, Van Landeghem GF, Sikstrom C, Wahlin A, Markevarn B, Hallmans G, Lenner P, Athlin L, Stenling R, Beckman L. Interaction between haemochromatosis and transferrin receptor genes in different neoplastic disorders. Carcinogenesis. 1999; 20:1231-1233.

57. Lloyd SJ, Lauble H, Prasad GS, Stout CD. The mechanism of aconitase: 1.8 A resolution crystal structure of the S642a:citrate complex. Protein Sci. 1999; 8:2655-2662.

58. Henderson BR. Iron regulatory proteins 1 and 2. BioEssays. 1996; 18:739-746.

59. Jeong SM, Lee J, Finley LW, Schmidt PJ, Fleming MD, Haigis MC. SIRT3 regulates cellular iron metabolism and cancer growth by repressing iron regulatory protein 1 . Oncogene. 2015; 34:2115-2124.

60. Haro KJ, Sheth A, Scheinberg DA. Dysregulation of IRP1mediated iron metabolism causes gamma ray-specific radioresistance in leukemia cells. PLoS ONE. 2012; $7: \mathrm{e} 48841$

61. Tan MG, Kumarasinghe MP, Wang SM, Ooi LL, Aw SE, Hui KM. Modulation of iron-regulatory genes in human hepatocellular carcinoma and its physiological consequences. Exp Biol Med (Maywood). 2009; 234:693-702.

62. Chen G, Fillebeen C, Wang J, Pantopoulos K. Overexpression of iron regulatory protein 1 suppresses growth of tumor xenografts. Carcinogenesis. 2007; 28:785-791.

63. Ogawara Y, Katsumoto T, Aikawa Y, Shima Y, Kagiyama Y, Soga T, Matsunaga H, Seki T, Araki K, Kitabayashi I. IDH2 and NPM1 Mutations Cooperate to Activate Hoxa9/Meis1 and Hypoxia Pathways in Acute Myeloid Leukemia. Cancer Res. 2015; 75:2005-2016.

64. Kats LM, Reschke M, Taulli R, Pozdnyakova O, Burgess K, Bhargava P, Straley K, Karnik R, Meissner A, Small D, $\mathrm{Su}$ SM, Yen K, Zhang J, et al. Proto-oncogenic role of mutant IDH2 in leukemia initiation and maintenance. Cell Stem Cell. 2014; 14:329-341.

65. Mylonas E, Janin M, Bawa O, Opolon P, David M, Quivoron C, Bernard OA, Ottolenghi C, DeBotton S, Penard-Lacronique V. Isocitrate dehydrogenase (IDH)2 R140Q mutation induces myeloid and lymphoid neoplasms in mice. Leukemia. 2014; 28:1343-1346.

66. Sasaki M, Knobbe CB, Munger JC, Lind EF, Brenner D, Brustle A, Harris IS, Holmes R, Wakeham A, Haight J, You-Ten A, Li WY, Schalm S, et al. IDH1(R132H) mutation increases murine haematopoietic progenitors and alters epigenetics. Nature. 2012; 488:656-659. 
67. Kuhn LC. Iron regulatory proteins and their role in controlling iron metabolism. Metallomics. 2015; 7:232-243.

68. Guo B, Phillips JD, Yu Y, Leibold EA. Iron regulates the intracellular degradation of iron regulatory protein 2 by the proteasome. J Biol Chem. 1995; 270:21645-21651.

69. Guo B, Brown FM, Phillips JD, Yu Y, Leibold EA. Characterization and expression of iron regulatory protein 2 (IRP2). Presence of multiple IRP2 transcripts regulated by intracellular iron levels. J Biol Chem. 1995; 270:16529-16535.

70. Fehringer G, Liu G, Pintilie M, Sykes J, Cheng D, Liu N, Chen Z, Seymour L, Der SD, Shepherd FA, Tsao MS, Hung RJ. Association of the 15q25 and 5p15 lung cancer susceptibility regions with gene expression in lung tumor tissue. Cancer Epidemiol Biomarkers Prev. 2012; 21:1097-1104

71. Wang W, Deng Z, Hatcher H, Miller LD, Di X, Tesfay L, Sui G, D'Agostino RB, Jr., Torti FM, Torti SV. IRP2 regulates breast tumor growth. Cancer Res. 2014; 74:497-507.

72. Hamara K, Bielecka-Kowalska A, Przybylowska-Sygut K, Sygut A, Dziki A, Szemraj J. Alterations in expression profile of iron-related genes in colorectal cancer. Mol Biol Rep. 2013; 40:5573-5585.

73. Maffettone C, Chen G, Drozdov I, Ouzounis C, Pantopoulos K. Tumorigenic properties of iron regulatory protein 2 (IRP2) mediated by its specific 73-amino acids insert. PLoS ONE. 2010; 5:e10163

74. Wang J, Chen GH, Muckenthaler M, Galy B, Hentze MW, Pantopoulos K. Iron-mediated degradation of IRP2, an unexpected pathway involving a 2-oxoglutarate-dependent oxygenase activity. Mol Cell Biol. 2004; 24:954-965.

75. Zutz A, Gompf S, Schagger H, Tampe R. Mitochondrial $\mathrm{ABC}$ proteins in health and disease. Biochim Biophys Acta. 2009; 1787:681-690.

76. Chen W, Paradkar PN, Li L, Pierce EL, Langer NB, Takahashi-Makise N, Hyde BB, Shirihai OS, Ward DM, Kaplan J, Paw BH. Abcb10 physically interacts with mitoferrin-1 (Slc25a37) to enhance its stability and function in the erythroid mitochondria. Proc Natl Acad Sci USA. 2009; 106:16263-16268.

77. Chen W, Dailey HA, Paw BH. Ferrochelatase forms an oligomeric complex with mitoferrin-1 and Abcb10 for erythroid heme biosynthesis. Blood. 2010; 116:628-630.

78. Yamamoto $\mathrm{M}$, Arimura $\mathrm{H}$, Fukushige $\mathrm{T}$, Minami $\mathrm{K}$, Nishizawa Y, Tanimoto A, Kanekura T, Nakagawa M, Akiyama S, Furukawa T. Abcb10 role in heme biosynthesis in vivo: Abcb10 knockout in mice causes anemia with protoporphyrin IX and iron accumulation. Mol Cell Biol. 2014; 34:1077-1084.

79. Shirihai OS, Gregory T, Yu C, Orkin SH, Weiss MJ. ABC-me: a novel mitochondrial transporter induced by GATA-1 during erythroid differentiation. EMBO J. 2000; 19:2492-2502.

80. Banci L, Brancaccio D, Ciofi-Baffoni S, Del CR, Gadepalli R, Mikolajczyk M, Neri S, Piccioli M,
Winkelmann J. [2Fe-2S] cluster transfer in iron-sulfur protein biogenesis. Proc Natl Acad Sci USA. 2014; 111:6203-6208.

81. Johansson C, Roos AK, Montano SJ, Sengupta R, Filippakopoulos P, Guo K, von DF, Holmgren A, Oppermann U, Kavanagh KL. The crystal structure of human GLRX5: iron-sulfur cluster co-ordination, tetrameric assembly and monomer activity. Biochem J. 2011; 433:303-311.

82. Shenton D, Perrone G, Quinn KA, Dawes IW, Grant CM. Regulation of protein S-thiolation by glutaredoxin 5 in the yeast Saccharomyces cerevisiae. J Biol Chem. 2002; 277:16853-16859.

83. Ye H, Rouault TA. Erythropoiesis and iron sulfur cluster biogenesis. Adv Hematol. 2010; 2010:

84. Camaschella C. Hereditary sideroblastic anemias: pathophysiology, diagnosis, and treatment. Semin Hematol. 2009; 46:371-377.

85. Liu G, Wang Y, Anderson GJ, Camaschella C, Chang Y, Nie G. Functional Analysis of GLRX5 Mutants Reveals Distinct Functionalities of GLRX5 Protein. J Cell Biochem. 2015; 117:207-217.

86. Mollbrink A, Jawad R, Vlamis-Gardikas A, Edenvik P, Isaksson B, Danielsson O, Stal P, Fernandes AP. Expression of thioredoxins and glutaredoxins in human hepatocellular carcinoma: correlation to cell proliferation, tumor size and metabolic syndrome. Int J Immunopathol Pharmacol. 2014; 27:169-183.

87. Lill R, Srinivasan V, Muhlenhoff U. The role of mitochondria in cytosolic-nuclear iron-sulfur protein biogenesis and in cellular iron regulation. Curr Opin Microbiol. 2014; 22:111-119.

88. Yan LJ, Levine RL, Sohal RS. Oxidative damage during aging targets mitochondrial aconitase. Proc Natl Acad Sci USA. 1997; 94:11168-11172.

89. Rouault TA, Stout CD, Kaptain S, Harford JB, Klausner RD. Structural relationship between an iron-regulated RNAbinding protein (IRE-BP) and aconitase: Functional implications. Cell. 1991; 64:881-883.

90. Mastrogiannaki M, Matak P, Peyssonnaux C. The gut in iron homeostasis: role of HIF-2 under normal and pathological conditions. Blood. 2013; 122:885-892.

91. Hausmann A, Lee J, Pantopoulos K. Redox control of iron regulatory protein 2 stability. FEBS Lett. 2011; 585:687-692.

92. Heddleston JM, Li Z, Lathia JD, Bao S, Hjelmeland AB, Rich JN. Hypoxia inducible factors in cancer stem cells. Br J Cancer. 2010; 102:789-795.

93. Zhen Q, Liu JF, Liu JB, Wang RF, Chu WW, Zhang YX, Tan GL, Zhao XJ, Lv BL. Endothelial PAS domaincontaining protein 1 confers TKI-resistance by mediating EGFR and MET pathways in non-small cell lung cancer cells. Cancer Biol Ther. 2015; 16:549-557.

94. Raspaglio G, Petrillo M, Martinelli E, Li Puma DD, Mariani M, De DM, Filippetti F, Mozzetti S, Prislei S, Zannoni GF, Scambia G, Ferlini C. Sox9 and Hif-2alpha 
regulate TUBB3 gene expression and affect ovarian cancer aggressiveness. Gene. 2014; 542:173-181.

95. Toledo RA, Qin Y, Srikantan S, Morales NP, Li Q, Deng Y, Kim SW, Pereira MA, Toledo SP, Su X, Aguiar RC, Dahia PL. In vivo and in vitro oncogenic effects of HIF2A mutations in pheochromocytomas and paragangliomas. Endocr Relat Cancer. 2013; 20:349-359.

96. Comino-Mendez I, de Cubas AA, Bernal C, Alvarez-Escola C, Sanchez-Malo C, Ramirez-Tortosa CL, Pedrinaci S, Rapizzi E, Ercolino T, Bernini G, Bacca A, Leton R, Pita G, et al. Tumoral EPAS1 (HIF2A) mutations explain sporadic pheochromocytoma and paraganglioma in the absence of erythrocytosis. Hum Mol Genet. 2013; 22:2169-2176.

97. Favier J, Lapointe S, Maliba R, Sirois MG. HIF2 alpha reduces growth rate but promotes angiogenesis in a mouse model of neuroblastoma. BMC Cancer. 2007; 7:139

98. Bangoura G, Liu ZS, Qian Q, Jiang CQ, Yang GF, Jing S. Prognostic significance of HIF-2alpha/EPAS1 expression in hepatocellular carcinoma. World J Gastroenterol. 2007; 13:3176-3182.

99. Xia G, Kageyama Y, Hayashi T, Hyochi N, Kawakami S, Kihara K. Positive expression of HIF-2alpha/EPAS1 in invasive bladder cancer. Urology. 2002; 59:774-778.

100. Hervouet E, Cizkova A, Demont J, Vojtiskova A, Pecina P, Franssen-van Hal NL, Keijer J, Simonnet H, Ivanek R, Kmoch S, Godinot C, Houstek J. HIF and reactive oxygen species regulate oxidative phosphorylation in cancer. Carcinogenesis. 2008; 29:1528-1537.

101. Heckler EJ, Alon A, Fass D, Thorpe C. Human quiescinsulfhydryl oxidase, QSOX1: probing internal redox steps by mutagenesis. Biochemistry. 2008; 47:4955-4963.

102. Heckler EJ, Rancy PC, Kodali VK, Thorpe C. Generating disulfides with the Quiescin-sulfhydryl oxidases. Biochim Biophys Acta. 2008; 1783:567-577.

103. Coppock DL, Thorpe C. Multidomain flavin-dependent sulfhydryl oxidases. Antioxid Redox Signal. 2006; 8:300-311.

104. Coppock DL, Cina-Poppe D, Gilleran S. The quiescin Q6 gene (QSCN6) is a fusion of two ancient gene families: thioredoxin and ERV1. Genomics. 1998; 54:460-468.

105. Lange H, Lisowsky T, Gerber J, Muhlenhoff U, Kispal G, Lill R. An essential function of the mitochondrial sulfhydryl oxidase Erv1p/ALR in the maturation of cytosolic $\mathrm{Fe} / \mathrm{S}$ proteins. EMBO Rep. 2001; 2:715-720.

106. Lake DF, Faigel DO. The emerging role of QSOX1 in cancer. Antioxid Redox Signal. 2014; 21:485-496.

107. Das P, Siegers GM, Postovit LM. Illuminating luminal B: QSOX1 as a subtype-specific biomarker. Breast Cancer Res. 2013; 15:104

108. Katchman BA, Ocal IT, Cunliffe HE, Chang YH, Hostetter G, Watanabe A, LoBello J, Lake DF. Expression of quiescin sulfhydryl oxidase 1 is associated with a highly invasive phenotype and correlates with a poor prognosis in Luminal B breast cancer. Breast Cancer Res. 2013; 15:R28.

109. Soloviev M, Esteves MP, Amiri F, Crompton MR, Rider CC. Elevated transcription of the gene QSOX1 encoding quiescin Q6 sulfhydryl oxidase 1 in breast cancer. PLoS ONE. 2013; 8:e57327

110. Araujo DG, Nakao L, Gozzo P, Souza CD, Balderrama V, Gugelmin ES, Kuczynski AP, Olandoski M, de NL. Expression level of quiescin sulfhydryl oxidase 1 (QSOX1) in neuroblastomas. Eur J Histochem. 2014; 58:2228

111. Gottschling S, Granzow M, Kuner R, Jauch A, Herpel E, Xu EC, Muley T, Schnabel PA, Herth FJ, Meister M. Mesenchymal stem cells in non-small cell lung cancer-different from others? Insights from comparative molecular and functional analyses. Lung Cancer. 2013; 80:19-29.

112. Katchman BA, Antwi K, Hostetter G, Demeure MJ, Watanabe A, Decker GA, Miller LJ, Von Hoff DD, Lake DF. Quiescin sulfhydryl oxidase 1 promotes invasion of pancreatic tumor cells mediated by matrix metalloproteinases. Mol Cancer Res. 2011; 9:1621-1631.

113. Poillet L, Pernodet N, Boyer-Guittaut M, Adami P, Borg C, Jouvenot M, Delage-Mourroux R, Despouy G. QSOX1 inhibits autophagic flux in breast cancer cells. PLoS ONE. 2014; 9:e86641

114. Ilani T, Alon A, Grossman I, Horowitz B, Kartvelishvily E, Cohen SR, Fass DA. secreted disulfide catalyst controls extracellular matrix composition and function. Science. 2013; 341:74-76.

115. Anderson GJ, Frazer DM, McKie AT, Vulpe CD. The ceruloplasmin homolog hephaestin and the control of intestinal iron absorption. Blood Cells Mol Dis. 2002; 29:367-375.

116. Hahn P, Qian Y, Dentchev T, Chen L, Beard J, Harris ZL, Dunaief JL. Disruption of ceruloplasmin and hephaestin in mice causes retinal iron overload and retinal degeneration with features of age-related macular degeneration. Proc Natl Acad Sci USA. 2004; 101:13850-13855.

117. Cherukuri S, Potla R, Sarkar J, Nurko S, Harris ZL, Fox PL. Unexpected role of ceruloplasmin in intestinal iron absorption. Cell Metabolism. 2005; 2:309-319.

118. Kuo YM, Su T, Chen H, Attieh Z, Syed BA, McKie AT, Anderson GJ, Gitschier J, Vulpe CD. Mislocalisation of hephaestin, a multicopper ferroxidase involved in basolateral intestinal iron transport, in the sex linked anaemia mouse. Gut. 2004; 53:201-206.

119. Vulpe CD, Kuo YM, Murphy TL, Cowley L, Askwith C, Libina N, Gitschier J, Anderson GJ. Hephaestin, a ceruloplasmin homologue implicated in intestinal iron transport, is defective in the sla mouse. Nat Genet. 1999; 21:195-199.

120. Agudo A, Bonet C, Sala N, Munoz X, Aranda N, FonsecaNunes A, Clavel-Chapelon F, Boutron-Ruault MC, Vineis P, Panico S, Palli D, Tumino R, Grioni S, et al. Hemochromatosis (HFE) gene mutations and risk of gastric cancer in the European Prospective Investigation into Cancer and Nutrition (EPIC) study. Carcinogenesis. 2013; 34:1244-1250.

121. Kallianpur AR, Hall LD, Yadav M, Christman BW, Dittus RS, Haines JL, Parl FF, Summar ML. Increased 
prevalence of the HFE C282Y hemochromatosis allele in women with breast cancer. Cancer Epidemiol Biomarkers Prev. 2004; 13:205-212.

122. Shaheen NJ, Silverman LM, Keku T, Lawrence LB, Rohlfs EM, Martin CF, Galanko J, Sandler RS. Association between hemochromatosis (HFE) gene mutation carrier status and the risk of colon cancer. JNCI. 2003; 95:154-159.

123. Mims MP, Prchal JT. Divalent metal transporter 1 . Hematology. 2005; 10:339-345.

124. Kovar J, Neubauerova J, Cimburova M, Truksa J, Balusikova K, Horak J. Stimulation of non-transferrin iron uptake by iron deprivation in K562 cells. Blood Cells Mol Dis. 2006; 37:95-99.

125. Xue X, Ramakrishnan SK, Weisz K, Triner D, Xie L, Attili D, Pant A, Gyorffy B, Zhan M, Carter-Su C, Hardiman KM, Wang TD, Dame MK, et al. Iron Uptake via DMT1 Integrates Cell Cycle with JAK-STAT3 Signaling to Promote Colorectal Tumorigenesis. Cell Metab. 2016; S1550-4131:30361-30368.

126. Kuhn LC. Iron regulatory proteins and their role in controlling iron metabolism. Metallomics. 2015; 7:232-243.

127. Lamy PJ, Durigova A, Jacot W. Iron homeostasis and anemia markers in early breast cancer. Clin Chim Acta. 2014; 434:34-40.

128. Zhao Z, Li C, Hu M, Li J, Liu R. Plasma ferritin levels, HFE polymorphisms, and risk of pancreatic cancer among Chinese Han population. Tumour Biol. 2014; 35:7629-7633.

129. Lobello N, Biamonte F, Pisanu ME, Faniello MC, Jakopin Z, Chiarella E, Giovannone ED, Mancini R, Ciliberto G, Cuda G, Costanzo F. Ferritin heavy chain is a negative regulator of ovarian cancer stem cell expansion and epithelial to mesenchymal transition. Oncotarget. 2016; 7:62019-62033. doi: 10.18632/oncotarget.11495.

130. Jenkitkasemwong S, Wang CY, Coffey R, Zhang W, Chan A, Biel T, Kim JS, Hojyo S, Fukada T, Knutson MD. SLC39A14 Is Required for the Development of Hepatocellular Iron Overload in Murine Models of Hereditary Hemochromatosis. Cell Metab. 2015; 22:138-150.

131. Liuzzi JP, Aydemir F, Nam H, Knutson MD, Cousins RJ. Zip14 (Slc39a14) mediates non-transferrin-bound iron uptake into cells. Proc Natl Acad Sci USA. 2006; 103:13612-13617.

132. Franklin RB, Levy BA, Zou J, Hanna N, Desouki MM, Bagasra O, Johnson LA, Costello LC. ZIP14 zinc transporter downregulation and zinc depletion in the development and progression of hepatocellular cancer. J Gastrointest Cancer. 2012; 43:249-257.

133. Thomas C, Oates PS. Ferroportin/IREG-1/MTP-1/ SLC40A1 modulates the uptake of iron at the apical membrane of enterocytes. Gut. 2004; 53:44-49.

134. Delaby C, Pilard N, Goncalves AS, Beaumont C, CanonneHergaux F. Presence of the iron exporter ferroportin at the plasma membrane of macrophages is enhanced by iron loading and downregulated by hepcidin. Blood. 2005; 106:3979-3984.

135. Dubrovska A, Hartung A, Bouchez LC, Walker JR, Reddy VA, Cho CY, Schultz PG. CXCR4 activation maintains a stem cell population in tamoxifen-resistant breast cancer cells through AhR signalling. Br J Cancer. 2012; 107:43-52.

136. Ojo D, Wei F, Liu Y, Wang E, Zhang H, Lin X, Wong N, Bane A, Tang D. Factors Promoting Tamoxifen Resistance in Breast Cancer via Stimulating Breast Cancer Stem Cell Expansion. Curr Med Chem. 2015; 22:2360-2374.

137. Piva M, Domenici G, Iriondo O, Rabano M, Simoes BM, Comaills V, Barredo I, Lopez-Ruiz JA, Zabalza I, Kypta R, Vivanco M. Sox2 promotes tamoxifen resistance in breast cancer cells. EMBO Mol Med. 2014; 6:66-79.

138. Orino K, Lehman L, Tsuji Y, Ayaki H, Torti SV, Torti FM Ferritin and the response to oxidative stress. Biochem J. $2001 ; 357: 241-247$.

139. Guibal FC, Alberich-Jorda M, Hirai H, Ebralidze A, Levantini E, Di RA, Zhang P, Santana-Lemos BA, Neuberg D, Wagers AJ, Rego EM, Tenen DG. Identification of a myeloid committed progenitor as the cancer-initiating cell in acute promyelocytic leukemia. Blood. 2009; 114:5415-5425.

140. Schmitt S, Saathoff F, Meissner L, Schropp EM, Lichtmannegger J, Schulz S, Eberhagen C, Borchard S, Aichler M, Adamski J, Plesnila N, Rothenfusser S, Kroemer G, et al. A semi-automated method for isolating functionally intact mitochondria from cultured cells and tissue biopsies. Anal Biochem. 2013; 443:66-74.

141. Christova T, Templeton DM. Effect of hypoxia on the binding and subcellular distribution of iron regulatory proteins. Mol Cell Biochem. 2007; 301:21-32.

142. Oliveira L, Drapier JC. Down-regulation of iron regulatory protein 1 gene expression by nitric oxide. Proc Natl Acad Sci USA. 2000; 97:6550-6555. 